\title{
Tko su antimaskeri u Hrvatskoj? Prilog istraživanju antimaskerske reakcije tijekom pandemije bolesti COVID-19 u Hrvatskoj ${ }^{1}$
}

\author{
Branko Ančić \\ Institut za društvena istraživanja u Zagrebu, Hrvatska \\ e-mail:branko@idi.hr
}

\author{
Dražen Cepić \\ Sveučilište u Zadru, Odjel za sociologiju, Hrvatska \\ e-mail:dcepic@unizd.hr
}

SAŽETAK Od samog početka pandemije bolesti COVID-19 alternativni narativi pojavljivali su se ne samo u virtualnim prostorima već i kao dio oficijelnijih objašnjenja društvenih aktera relevantnih za upravljanje pandemijskom krizom. Kao reakciju na širenje zaraze, vlasti posvuda uvode mjere karantene, obavezu poštivanja epidemioloških mjera, zatvaranje ekonomije (tzv. lockdown), što od ljeta pa kroz jesen i zimu 2020. godine dovodi do prosvjeda protiv mjera u nizu svjetskih gradova, kao što su Berlin, London, Bruxelles, Dublin, Madrid, Pariz, Rotterdam pa i Zagreb (tzv. antimaskerski prosvjedi). U ovom radu pod pojmom antimaskerstva promatramo društveni fenomen koji ne govori samo o pukoj činjenici nenošenja maski kao činu kršenja epidemiološke mjere već i o reakciji ljudi tijekom pandemije koja obuhvaća percepciju koja umanjuje opasnost od virusa SARS-CoV-2 ili čak i negira njegovo postojanje te ujedno i procjenu ljudi kako su nametnute epidemiološke mjere opresivne (pretjerano stroge). Teorijski okvir rada temelji se na literaturi o teorijama zavjera kao krovnom konceptu koji pomaže u razumijevanju navedenih antimaskerskih pokreta. $U$ analizi su korišteni podaci prikupljeni anketnim upitnikom (CATI tehnikom) tijekom kolovoza, rujna i listopada 2020. godine na nacionalno reprezentativnom uzorku $(\mathrm{N}=1512)$. U radu su analizirane neke od determinanti sklonosti teorijama zavjera kao moguće eksplanatorne determinante antimaskerske društvene reakcije. U analizi se dva aspekta pokazuju ključnima u razumijevanju antimaskerske društvene reakcije - egzistencijalni uvjeti i promjene tih uvjeta uslijed pandemije te povjerenje u relevantne društvene aktere/institucije u upravljanju krizom izazvanom bolešću COVID-19.

Ključne riječi: pandemija bolesti COVID-19, antimaskerstvo, teorije zavjere, pridržavanje epidemioloških mjera.

1 Ovaj rad nastao je u sklopu projekta Otpornost hrvatskog drustva uslijed COVID-19 pandemije (IP-CORONA-04-2044) financiranog od strane Hrvatske zaklade za znanost (HRZZ-CORONA).

Copyright (C) 2021 Institut za društvena istraživanja u Zagrebu - Institute for Social Research in Zagreb Sva prava pridržana - All rights reserved 


\section{Uvod}

Čini se kako je prvi slučaj oboljenja od bolesti COVID-19 zabilježen već 17. studenog 2019. godine, radilo se o pedesetpetogodišnjem muškarcu iz provincije Hubei u $\mathrm{Kini}^{2}{ }^{2}$ Prema objašnjenju koje je trenutno najviše zastupljeno u znanstvenoj zajednici, zaraza virusom SARS-CoV2 nastala je kao zoonotska transmisija virusa sa šišmiša na mravojeda te potom na čovjeka. Do kraja prosinca 2019. godine izbija zaraza u kineskom gradu Wuhanu, do sredine siječnja 2020. virus se širi diljem Azije te potom do kraja siječnja na ostale kontinente. Kao reakciju na širenje zaraze, vlasti posvuda uvode mjere karantene, obavezu poštivanja epidemioloških mjera, zatvaranje ekonomije (tzv. lockdown), što od ljeta pa kroz jesen i zimu 2020. godine dovodi do prosvjeda protiv mjera u nizu svjetskih gradova, kao što su Berlin, London, Bruxelles, Dublin, Madrid, Pariz, Rotterdam pa i Zagreb.

Usprkos razlikama u epidemiološkim procjenama oko najboljih mjera te prijedlozima kako politički i institucionalno artikulirati te mjere, globalna znanstvena zajednica slaže se oko osnovnih činjenica: da virus SARS-CoV2 postoji, da je opasan za zdravlje, odnosno da je kroz političke i administrativne mjere nužno suzbiti njegovo širenje. Usprkos konsenzusu, mjere posvuda izazivaju protivljenje i prosvjede, koji se, po tome što maske uzimaju kao simbol mjera kojima se protive, u dijelu medija i javnosti nazivaju ,antimaskerskim“ prosvjedima. Cilj ovog rada jest rasvijetliti odluku i razloge onih koji, odbijajući preporuke znanstvene i medicinske zajednice te političkih vlasti, izražavaju protivljenje epidemiološkim mjerama. Stoga u ovom radu pod pojmom antimaskerstva promatramo društveni fenomen koji ne govori samo o pukoj činjenici nenošenja maski kao činu kršenja epidemiološke mjere već i o reakciji ljudi tijekom pandemije koja obuhvaća percepciju koja umanjuje opasnost od virusa SARS-CoV-2 ili čak i negira njegovo postojanje te ujedno i procjenu ljudi kako su nametnute epidemiološke mjere opresivne (pretjerano stroge). U određenoj mjeri istražujemo potencijal društvenih reakcija koje su svoju ekspoziciju imale u prosvjedima organiziranima u brojnim gradovima diljem svijeta, dok su u Hrvatskoj od vidljivijih bila dva prosvjeda organizirana pod nazivom Festival slobode. $U$ tom smislu ne istražujemo same prosvjede niti direktno ljude koji su sudjelovali u njima, već istražujemo percepcije i stavove vezane za pandemiju bolesti COVID-19 koji su relevantni u kontekstu artikulacije društvene reakcije koja umanjuje opasnost od virusa SARS-CoV-2 i koja pokazuje otpor i kritiku prema epidemiološkim mjerama za suzbijanje širenja pandemije.

$\mathrm{Na}$ kraju, socijalna mobilizacija oko protivljenja epidemiološkim mjerama predstavlja vrlo recentan fenomen, o kojem postoje tek vrlo ograničena istraživanja. Međutim, sam fenomen protivljenja medicinskim mjerama i znanstvenim autoritetima koje podupiru politički aparati nije nov. U više ili manje organiziranim formama, s tim smo

2 https://www.livescience.com/first-case-coronavirus-found.html. (Preuzeto 19. 1. 2021.). 
upoznati kroz razne oblike društvenih pokreta, kao što su protivnici cijepljenja (tzv. antivakseri) ili protivnici mreža 5G. S obzirom na te „obiteljske sličnosti“ koje antimaskerski prosvjedi dijele s drugim oblicima otpora, kao teorijski okvir za pristup tim podacima u ovom se radu služimo literaturom o alternativnim narativima, odnosno teorijama zavjera, kao krovnom konceptu koji pomaže u razumijevanju navedenih antimaskerskih pokreta. Kako su se stavovi protivljenja nošenju maski povezivali s alternativnim narativima i mitovima o pandemiji bolesti COVID-19, u ovom radu analizirat ćemo neke od determinanti sklonosti teorijama zavjera kao moguće eksplanatorne determinante antimaskerske društvene reakcije.

Stoga u teorijskom okviru predstavljamo istraživanja teorija zavjera, ističemo glavne analitičke koncepte koje koristimo u svojoj analizi te u zasebnoj sekciji objašnjavamo relevantnost teorija zavjere za shvaćanje protivljenja epidemiološkim mjerama. Potom u sekciji o metodologiji opisujemo načine prikupljanja i analitičke strategije obrade podataka te navodimo indikatore na temelju kojih smo konstruirali zavisne i nezavisne varijable. Nakon toga slijede analiza te diskusija i zaključak rada.

\section{Teorijski okvir}

Historiografija pamti brojne političke zavjere, od ubojstva Cezara (44. godine pr. Kr.), preko Urote baruta (1605. godine), afere Dreyfus (1898. godine) do afere Watergate (1972. godine). Isto tako kako postoje realne zavjere tako se kroz povijest pojavljuju i teorije zavjera koje pokušavaju objasniti neke povijesne događaje i procese. Teorije zavjera pokušavaju objasniti teroristički napad 11. 9. 2011. godine u New Yorku kao dio poduhvata organiziranog od Busheve administracije, financijskih institucija i „židovskog lobija“. Isto tako klimatske promjene, za one koji tvrde da nisu posljedica ljudskog djelovanja na planetu Zemlji, zaplotnjaštvo su Ujedinjenih naroda, znanstvenika, komunista, vlada pa čak i naftne industrije. Pandemija COVID-19 isto je tako tumačena različitim teorijama zavjere, od interpretacija kako se radi o virusu koji su kreirali znanstvenici u kineskom laboratoriju, preko toga kako se prenosi kroz mobilnu mrežu 5G do toga kako Bill Gates želi masovno procijepiti svjetsku populaciju s namjerom da ubije većinu ljudi. Alternativnog narativa o pandemiji bolesti COVID-19 ne nedostaje.

Razlika između teorija zavjera i realnih zavjera u tome je što se zavjere odnose na istinit kauzalni slijed događaja, dok se teorije zavjera odnose na navodne zavjere, koje mogu i ne moraju biti istinite. Stoga teorije zavjera u širem smislu možemo definirati kao uvjerenja da dvoje ili više moćnih aktera ili institucija, kroz zaplotnjaštvo i na skriven način, utječe na značajne društvene i političke događaje (Keeley, 1999.; Pigden, 1995.; Sunstein i Vermeule, 2008.). Premda neki smatraju kako teorije zavjera, budući da se pojavljuju među građanima, nije smisleno promatrati kao vrstu socijalne patologije (Oliver i Wood, 2014.), većina autora smatra da one predstavljaju važan predmet 
znanstvenog proučavanja s obzirom na njihove negativne učinke, poput zdravstvenih problema, radikalizacije ili pak porasta antagonizma u društvu (Jolley i Douglas, 2014.; Swami i Furnham, 2014.; van Prooijen i Acker, 2015.)

Zavjere, prema onima koji ih zastupaju, postoje s ciljem uzurpacije ekonomske i političke moći, pri čemu se kroz zavjere krše ljudska prava i zadržavaju relevantne informacije radi ostvarivanja određene koristi (van Prooijen i Acker, 2015.). Takva se uvjerenja protežu kroz različite teme, poput znanosti, migracije, zdravstva i zdravlja, okoliša, terorizma, religije, rasizma, međunarodnih odnosa, pri čemu je njihova glavna namjera u tome da objasne i razotkriju ulogu aktera tih zavjera, koja je intencionalno skrivena. Međutim, u užem smislu u kojem se koristi pojam u ovom radu, teorije zavjere dodatno se odnose na uvjerenja koja nisu prihvaćena među autoritetima, u znanstvenoj zajednici, mainstream medijima i sl. zbog toga što su utemeljena u slabim dokazima te na temelju toga što njihova argumentacija ne zadovoljava kriterije logičke rigoroznosti. U skladu s tim, Sunstein i Vermeule smještaju teorije zavjere u kategoriju lažnih uvjerenja, koja su ujedno i štetna (Sunstein i Vermeule, 2008.). Primjerice, kada govorimo o pandemiji COVID-19 i epidemiološkoj mjeri nošenja maske, lažno uvjerenje može biti kako nošenje maski ne pomaže smanjivanju prenošenja koronavirusa, no to nikako nije teorija zavjere. Iako se radi o lažnom uvjerenju koje je ujedno i štetno, ono kao takvo ne predstavlja teoriju zavjere. Za označavanje nečega etiketom teorije zavjere potrebna je atribucija izvanrednih moći određenim agentima/akterima u toj zavjeri. U tom smislu, ako je vjerovanje kako maske nisu učinkovite u borbi protiv pandemije i kako ih se ne treba nositi dio teorijsko-zavjereničkog promišljanja kako je pandemija COVID-19 posljedica aktivnosti „globalne vlade“ ili „židovskog lobija“ ili pak namjera Billa Gatesa da preuzme potpunu kontrolu nad cijelim svijetom, onda je to vjerovanje ekspozicija teorije zavjere. U tom smislu, antimaskerski impuls koji se pojavio u hrvatskom društvu, a koji je dio sličnih ili istih reakcija zabilježenih u drugim društvima, može se konceptualno promatrati kao posljedica teorija zavjera o pandemiji COVID-19.

Prema Goertzelovim istraživanjima, neki ljudi vjeruju u više teorija zavjere dok drugi ni u jednu. Na temelju toga Goertzel zaključuje kako zavjerenička vjerovanja konstruiraju monološke sustave vjerovanja (engl. monological belief system) u kojima se različite teorije zavjere međusobno podupiru, čak i kada su međusobno kontradiktorne. Zavjerenička vjerovanja u tom se smislu povezuju s drugim sličnim vjerovanjima. Zanimljivo je da se oni koji vjeruju u teorije zavjere kada im se određena teorija pokaže kao netočna, često okreću novim teorijama zavjere (Keeley, 1999.). Zašto, usprkos neprihvaćanju od eksperata i znanstvene zajednice, teorije zavjere svejedno nailaze na podršku? Prema Douglas, Sutton i Cichocka (2017.) privlačnost teorija zavjera proizlazi iz zadovoljavanja triju vrsta motiva: potrebe za spoznajom, potrebe za sigurnošću te potrebe za osjećajem samovrijednosti. 
Prvi se motiv odnosi na epistemičku potrebu za razumijevanjem svijeta u kojem živimo, što teorije zavjere omogućavaju pružajući širok, stabilan i konzistentan okvir razumijevanja svijeta. Konzistentnost se pritom često osigurava nauštrb istinitosti, budući da se kompleksna objašnjenja simplificiraju smještanjem u prethodno kreirane obrasce. U kojim se situacijama poseže za takvim simplificiranim eksplanatornim obrascima? To objašnjava drugi motiv. Naime, istraživanja su pokazala da se ljudi okreću teorijama zavjere onda kada se osjećaju nemoćnima (Abalakina-Paap i sur., 1999.) i anksioznima (Grzesiak-Feldman 2013.; Kofta i Sedek 2005.; Imhoff i Bruder 2014.). U nekim od znanstvenih eksperimenata pokazalo se kako su zavjerenička vjerovanja prisutnija onda kada ljudi osjećaju da ne mogu kontrolirati životne ishode, dok su manje prisutna onda kada ljudi osjećaju kako mogu kontrolirati životne ishode (van Prooijen i Acker, 2015.). Na kraju, treći eksplanatorni segment odnosi se na identitetski aspekt osjećaja nemoći, koji je često vezan za povlačenje simboličkih granica između „nas“ i „njih“ te na potrebu za održavanjem pozitivne slike o sebi i grupi kojoj ljudi pripadaju. Istraživanja su pokazala kako su teorije zavjera posebno privlačne ljudima u onim situacijama kada imaju dojam da je pozitivna slika o njima samima i o njihovim društvenim grupama ugrožena (Cichocka i sur., 2016.), odnosno kada imaju dojam o sebi i svojoj društvenoj grupi kao o kompetentnima i moralnima, ali ugroženima od beskrupuloznih i moćnih. Eksperimentalna istraživanja pokazuju kako iskustva ostraciziranja navode ljude da vjeruju u teorije zavjere, i to upravo kao pokušaj davanja smisla svojim iskustvima (Graeupner i Coman, 2017.). Vezano za važnost iskustva viktimizacije, neka istraživanja upućuju na sklonost vjerovanja teorijama zavjera kod onih koji se nalaze u nižim društvenim stratumima na temelju etniciteta, prihoda ili političke pripadnosti (Crocker i sur., 1999.; Uscinski i Parent, 2014.).

\section{Teorije zavjere i pandemija bolesti COVID-19}

Istraživanja pokazuju kako se sklonost teorijama zavjera pojačava u situacijama u kojima se zbivaju veliki i značajni događaji koji zbog nezadovoljavajućih objašnjenja potiču osjećaje bespomoćnosti, nesigurnosti, nepredvidljivosti te reduciraju razinu političkog povjerenja (Edelson i sur., 2017.; Leman i Cinnirella, 2013.; Moore, 2018.). Pandemija COVID-19 svakako predstavlja jedan takav događaj. Već u veljači 2020. godine, nakon što se virus počeo širiti globalno i nakon čega su počele restrikcije, zatvaranja državnih granica i uvođenje epidemioloških mjera kao što su nošenje maski i držanje fizičke distance, postalo je jasno kako se osim širenja virusa SARS-CoV2 jednakom brzinom šire i lažne vijesti. ${ }^{3}$

3 Čelnik Svjetske zdravstvene organizacije u veljači 2020. godine upozorava kako se „svijet ne bori samo s epidemijom već i infodemijom. Lažne vijesti šire se brže i lakše nego virus, pri čemu je to jednako opasno." World Health Organisation. (15. 2. 2020.). Munich security conference. https://www.who.int/dg/ speeches/detail/munich-security-conference 
Postojanje teorija zavjere u kontekstu pandemija nije samo po sebi novost. Alternativni narativi zabilježeni su i tijekom ranijih pandemija: primjerice vezano za virus HIV-a (Geissler i Sprinkle, 2013.; Bogart i sur., 1999.) te epidemiju virusa zika (Klofstad i sur., 2019.). Fenomen nekontroliranog širenja bolesti, naime, pruža idealne uvjete za širenje alternativnih narativa u više smislova: prvo, razumijevanje virusnih i bakterijskih bolesti često zahtijeva stručno znanje i kompleksna objašnjenja, koja predstavljaju izazov za epistemičku potrebu koju navode Sutton i Cichocka (2017.). Neznanstvena objašnjenja koja na simplificiran (i pogrešan) način predstavljaju kompleksne fenomene mogu se činiti primamljivima u odnosu na alternativnu mogućnost da razumijevanje fenomena prepustimo stručnjacima (znanstvenicima, zdravstvenim profesionalcima i sl.). Drugo, epidemiološki način nošenja s pandemijama često uključuje farmaceutsku industriju, koja je opravdano ili ne česta meta kritika zbog stavljanja ekonomskog profita ispred zdravlja konzumenata. Treće, fenomen pandemija često podrazumijeva administrativne restrikcije i upotrebu represivnog aparata, što još više ističe eventualne probleme demokratskog deficita i nepovjerenja u politički sustav. Ti su razlozi tek dodatak činjenici da pandemije na vrlo elementarnoj fenomenološkoj razini predstavljaju izvor tjeskobe i straha od bolesti, patnje i smrti.

U kontekstu pandemije COVID-19 dva su osnovna alternativna narativa: narativ o bezopasnosti virusa te narativ o umjetnom podrijetlu virusa. U prvom narativu opasnost se od virusa SARS-CoV-2 umanjuje njegovim svrstavanjem u kategoriju bolesti koja nije opasnija od gripe. Dok se sam virus SARS-CoV-2 prikazuje bezopasnim, razlog zašto mediji, političke elite i znanstvena zajednica propagiraju informacije o opasnosti virusa krije se u skrivenim intencijama da nametnu restriktivne zakone i mjere. Ako se vratimo na definiciju teorija zavjere kao uvjerenja da dvoje ili više moćnih aktera ili institucija, kroz zaplotnjaštvo i na skriven način, utječe na značajne društvene i političke događaje, vidi se da su sva tri kriterija ovdje zadovoljena: a) mediji, političke elite i znanstvena zajednica predstavljaju moćne aktere, b) ti akteri provode svoje nakane na skriven način (kako bi umanjili mogućnost otpora) te c) time nastoje utjecati na značajne društvene i političke događaje, odnosno na uvođenje restrikcija. Drugi se narativ od prvog značajno razlikuje po sadržaju: on se sastoji u negiranju prirodne pojavnosti samog virusa, pri čemu se pandemijska situacija prikazuje kao namjerno stvoren virus koji u ulozi biološkog oružja služi ekonomskim i političkim dobicima. Međutim, i taj narativ zadovoljava kriterije a) i b), dok se kriterij c) razlikuje po tome što se on sastoji u nakani da se demografski utječe na populaciju kroz desetkovanje određenih demografskih skupina, odnosno kroz eliminaciju dijelova stanovništva.

Oba narativa možemo jasno svrstati među teorije zavjere u užem smislu budući da pretežito nisu prihvaćeni od političke elite, mainstream medija ili u znanstvenoj zajednici, premda neki vrlo utjecajni članovi tih miljea u većoj ili manjoj mjeri preuzimaju alternativna objašnjenja. Također, posljedično oba narativa vode istom cilju: umanjivanju percepcije opasnost od virusa SARS-CoV-2, odnosno do toga da se epidemiološke mjere važne za borbu s pandemijom COVID-19 doživljavaju pretjeranima. Prvi nara- 
tiv taj cilj postiže na očit način, uvjeravanjem da je virus neopasan, dok drugi narativ do toga dolazi posredno: premda se ne dovodi u pitanje opasnost virusa, epidemiološke se mjere prikazuju uzaludnima budući da ih predlažu i provode iste one elite koje su odgovorne za nastanak virusa. Oba narativa, prema tome, dovode do umanjenja percepcije rizika od bolesti te do smanjenja zdravstveno-protektivnog ponašanja (Imhoff i Lamberty, 2020.).

\section{Istraživačka pitanja}

Prosvjedi protiv epidemioloških mjera, koji su u dijelu medija i javnosti nazvani „antimaskerskim" prosvjedima, predstavljaju medijski najvidljiviji iskaz takvog odbijanja; u Hrvatskoj dva su takva prosvjeda organizirana pod nazivom Festival slobode. Međutim, kada govorimo o protivljenju epidemiološkim mjerama, treba naglasiti da je riječ o širem fenomenu, koji se pored fizičkih protesta sastoji i od članstva u online grupama, komentiranja ispod medijskih objava, dijeljenja materijala po društvenim mrežama i drugih vidova protivljenja, koji se zajedno mogu klasificirati kao jedna vrsta društvenog pokreta.

U ovom radu ne analiziramo taj pokret sam po sebi, u smislu da analiziramo podatke o posjetiteljima prosvjeda protiv epidemioloških mjera ili o članovima antimaskerskih Facebook grupa. Umjesto toga tom smo problemu pristupili kroz analizu reprezentativnog nacionalnog uzorka, na temelju kojeg smo konstruirali poduzorak ispitanika za koje prema odabranim kriterijima tvrdimo da su najviše skloni zastupati takve stavove. $\mathrm{U}$ tom smislu, ovaj se rad ne bavi neposrednim istraživanjem samih antimaskerskih prosvjeda, već istraživanjem percepcija i stavova vezanih za pandemiju bolesti COVID-19 koji su relevantni u kontekstu artikulacije otpora prema epidemiološkim mjerama. Potom, informirano literaturom o teorijama zavjere, u radu istražujemo različite faktore i strukturalne razloge koji mogu poslužiti kao prediktori za takvo ponašanje.

Prvo, istražujemo povezanost otpora epidemiološkim mjerama sa stupnjem obrazovanja. Više studija navodi vezu sklonosti teorijama zavjera s nižim razinama obrazovanja (Uscinski i Parent 2014.; Freeman i Bentall 2017.; Bogart i Bird 2003.; Goerztzel 1994.; Mancosu, Vassallo i Vezzoni 2017.). Ta se povezanost objašnjava time da kroz sudjelovanje u obrazovnom procesu ljudi stječu znanja i kognitivne vještine koje omogućuju stvaranje određene otpornosti prema teorijama zavjera (Douglas i sur. 2019.), dok u slučaju nižeg stupnja obrazovanosti akteri koji nemaju odgovarajuće kognitivne vještine za shvaćanje kompleksnih fenomena pribjegavaju simplificiranim, neznanstvenim objašnjenjima.

Drugi aspekt u ovom istraživanju tiče se veze teorija zavjere i problema društvenog povjerenja, uključujući nepovjerenje u institucije te općenito društveno nepovjerenje. Važnost povjerenja očituje se iz same definicije teorija zavjere kao uvjerenja da dvoje ili više moćnih aktera ili institucija, kroz zaplotnjaštvo i na skriven način, utječe na 
značajne društvene i političke događaje. Kod niza fenomena koji predstavljaju povod za stvaranje teorija zavjere, kao što je pandemija COVID-19, riječ je o kompleksnim fenomenima čije potpuno shvaćanje zahtijeva specijalističko znanje, odnosno o fenomenima za čije shvaćanje velika većina ljudi (uključujući one visokoobrazovane) ovise o objašnjenjima stručnjaka. Pritom će oni koji imaju niži stupanj povjerenja u stručnjake, ali i druge ljude općenito, biti više skloni zastupati teorije zavjere. Prema literaturi, to je često praćeno osjećajem nemoći i tjeskobe, na koje se referiramo u teorijskom okviru (Abalakina-Paap i sur., 1999.; Grzesiak-Feldman, 2013.; van Prooijen i Acker, 2015.).

Treći aspekt koji istražujemo tiče se povezanosti protivljenja epidemiološkim mjerama i osjećaja materijalne ugroženosti. To temeljimo na istraživanjima koja ukazuju na to da su više razine sklonosti teorijama zavjera povezane $s$ nižim prihodovnim statusom (Uscinski i Parent, 2014.) te da su više zastupljene kod socijalno isključenih skupina, kao što su nezaposleni (Freeman i Bentall, 2017.). Taj je aspekt posebno izražen u slučaju pandemije COVID-19, koja predstavlja ne samo zdravstveni rizik već i faktor materijalne ugroženosti, s obzirom na zatvaranje velikih sektora ekonomije kao sastavni dio epidemioloških mjera. Drugim riječima, u radu nas je zanimalo je li protivljenje mjerama, pored ili osim veze s kognitivnim i afektivnim razlozima, ujedno povezano $s$ egzistencijalnom nesigurnošću nastalom uslijed pandemije COVID-19.

Četvrto, istraživanja ukazuju na to da je sklonost teorijama zavjera povezana s političkim uvjerenjima. Primjerice, istraživanja provedena u SAD-u, Nizozemskoj te Švedskoj pokazuju efekt „U-oblika“, sugerirajući kako se sklonost teorijama zavjera nalazi na radikalnijim dijelovima političkog spektra (lijevog i desnog) (van Prooijen i sur., 2015.; Krouwel i sur., 2018.). Druga istraživanja pokazuju kako je zavjereničko razmišljanje prisutnije kod onih koji se politički identificiraju s nezavisnima ili pak trećim političkim opcijama u jako izraženom dvostranačkom političkom prostoru (Uscinski i sur., 2016.), dok treći tvrde da se sklonost zavjereničkom vjerovanju i alternativnim narativima prije svega može pronaći na desnoj strani političkog spektra (Bruder i sur., 2013.; Grzesiak-Feldman i Irzycka, 2009.) (van Prooijen i sur., 2015.; Jost i sur., 2003.). To je stoga još jedan faktor koji istražujemo na svojim podacima.

\section{Metoda prikupljanja podataka i opis uzorka}

Podaci u ovom radu prikupljeni su u sklopu projekta „Otpornost hrvatskog društva uslijed COVID-19 pandemije“4. U sklopu projekta provedeno je inicijalno istraživanje tehnikom CATI s ciljem regrutacije ispitanika za sudjelovanje u longitudinalnom istraživanju s panel uzorkom koje će se organizirati tijekom 2021. godine. Istraživanje tehnikom CATI provedeno je u razdoblju od 20. kolovoza 2020. godine do 2 . listopada 2020. godine, u sklopu kojeg je sudjelovalo 1512 ispitanika. Istraživanje je

${ }^{4}$ HRZZ-CORONA projekt „Otpornost hrvatskog društva uslijed COVID-19 pandemije -SOCRES”, voditelj doc. dr. sc. Branko Ančić. 
provedeno u tri vremenska vala. U prvom (između 2. i 31. kolovoza) i trećem(između 15. rujna i 2. listopada) valu istraživanje je provedeno na nacionalno reprezentativnom slučajnom uzorku punoljetnih građana $\mathrm{RH}(\mathrm{N}=1212)$, pri čemu je okvir uzorka uključivao imenik fiksnih brojeva privatnih osoba iz 2011. godine. Uzorak je stratificiran dvoetapno prema regiji i veličini naselja te su kućanstva koja su odbrana za istraživanje birana metodom slučajnog odabira iz baze fiksnih telefonskih brojeva, dok su ispitanici u kućanstvu birani temeljem svojih karakteristika (kvote prema dobi i spolu). Procijenjena je margina pogreške $+/-2,81 \%$. Drugi je val (između 3. i 9. rujna) proveden na namjernom uzorku agencijskog panela $(\mathrm{N}=300)$. U sva tri vala struktura uzorka usklađena je sa strukturom populacije (prema podacima DZS-a iz 2019. godine) metodom utežavanja prema spolu, dobi i stupnju obrazovanja, uz kontrolu regionalne strukture prema kojoj je uzorak bio stratificiran (više o uzorku vidi u radu Šuljok i Bagić, 2021.), pri čemu je onda ukupni broj ispitanika koji se koristi u ovom radu 1512. Upitnikom se nastojalo istražiti značajnije promjene u populaciji nastale uslijed pandemije COVID-19, uključujući promjene u razini prihoda, uvjeta rada, osobnog i institucionalnog povjerenja, iskustva s bolesti uzrokovane virusom SARS-CoV-2, pridržavanju epidemioloških mjera te percepcije opasnosti uzrokovane koronavirusom.

\subsection{Zavisne varijable}

Zavisna varijabla kreirana je na temelju dvaju pitanja iz upitnika. Jedno pitanje odnosi se na procjenu strogosti epidemioloških mjera, pri čemu su ispitanici upitani „Jesu li mjere za kontrolu širenja virusa koje su trenutno na snazi prestroge, primjerene situaciji ili preblage?“. Moguće je bilo odabrati jedan od sljedećih odgovora: (1) mjere su prestroge, (2) mjere su primjerene situaciji, (3) mjere su preblage, (4) ne znam, ne mogu procijeniti. Drugo pitanje odnosi se na percepciju opasnosti uzrokovane virusom SARS-CoV-2, pri čemu su ispitanici upitani „Koliko je opasan koronavirus za zdravlje stanovništva?“. Moguće je bilo odabrati jedan od sljedećih odgovora: (1) iznimno opasan, posljedice bi mogle biti kobne za puno ljudi; (2) dosta opasan, ali posljedice za veliku većinu neće biti kobne; (3) donekle opasan, ali se pretjeruje sa strahom i oprezom; (4) manja opasnost, koronavirus je poput gripe; (5) nikakva opasnost, koronavirus zapravo ne postoji. Indikator antimaskerske reakcije konstruiran je tako da su oni odgovori u kojima se umanjuje opasnost od koronavirusa (odgovori 3, 4 i 5 na pitanju procjene opasnosti koronavirusa za zdravlje stanovništva) pridruženi odgovoru (1) mjere su prestroge iz pitanja o procjeni strogosti epidemioloških mjera.

Korištenje prvog indikatora za potrebe zavisne varijable relativno je jasno budući da istražujemo protivljenje epidemiološkim mjerama; prosvjedi, vršenje pritiska kroz društvene mreže i sl. namijenjeni su upravo ukidanju epidemioloških mjera. Međutim, ukoliko bismo istraživali jedino protivljenje epidemiološkim mjerama, time bismo zahvatili širi krug ljudi, od kojih se neki ne mogu uvrstiti među teoretičare zavjere, poput npr. liberalnih ekonomista i znanstvenika bliskih poduzetničkom mi- 
ljeu. Ono što je specifično za potonje jest da se protive epidemiološkim mjerama, a da pritom ne osporavaju autoritet znanosti niti kreiraju alternative narative, već osporavaju prvenstveno političku artikulaciju prijedloga koji dolaze iz epidemioloških krugova, a koji idu u smjeru zatvaranja određenih sektora ekonomije. $S$ obzirom na prethodno opisani fokus ovog rada, kao dodatni indikator uzeli smo i drugu mjeru: sumnju u opasnost virusa.

Uz taj indikator u analizi je korišten i indeks nepoštivanja epidemioloških mjera. Taj je indeks konstruiran na temelju baterija pitanja o samoprocjeni zdravstveno odgovornog ponašanja u skladu s preporučenim epidemiološkim mjerama. Ispitanici su trebali odgovorima da ili ne procijeniti: (a) peru li ili dezinficiraju ruke češće nego inače; (b) nose li zaštitnu masku za lice tamo gdje je to propisano kao obavezno, primjerice u trgovinama i javnom prijevozu; (c) nose li zaštitnu masku za lice čim izađu iz svog doma; (d) održavaju li razmak od 1,5 m od drugih osoba koje nisu članovi njihovog kućanstva; (e) izbjegavaju li odlaske u kafiće i restorane; (f) izbjegavaju li javna mjesta/ događanja; (g) izbjegavaju li kontakt s rizičnim skupinama (starijim osobama, ljudima $s$ kroničnim bolestima); (h) nastoje li smanjiti broj i učestalost društvenih kontakata. Raspon je indeksa od 0 do 8 , pri čemu više vrijednosti označavaju višu razinu nepoštivanja epidemioloških mjera $(M=2,44 ; s d=1,86)$.

\subsection{Nezavisne varijable}

Kako bi se testirali učinci promjena egzistencijalnih uvjeta ispitanika i kućanstava na percepciju opasnosti koronavirusa i adekvatnosti epidemioloških mjera, korišteno je šest indikatora: ESeG-indikator klasne strukture, radni status, rad u privatnom ili javnom sektoru, procjena smanjenja prihoda zbog pandemije koronavirusa, iskustvo gubitka posla zbog pandemije, ukupni prihodi kućanstva.

Indikator ESeG (European Socio-economic Groups) indikator je klasne strukture društva koji koristi dvije varijable - ISCO08 zanimanje i radni status (zaposlenik/ samozaposleni, umirovljenik/student/invalid) (Tijdens, 2016.). Konceptualna logika za ESeG jest podijeliti cjelokupno stanovništvo na društveno-ekonomske skupine koje su u određenoj mjeri koherentne koristeći kriterij autonomije u zapošljavanju i ljudskom kapitalu (Ančići i sur., 2019.a, 2019.b; Holý i Strašilová, 2015.). ESeG skupine na prvoj razini podjela su: ESeG1-menadžeri, ESeG2-profesionalci, ESeG3-tehničari i pridruženi profesionalni zaposlenici, ESeG4-mali poduzetnici, ESeG5-službenici i kvalificirani uslužni djelatnici, ESeG6-industrijski i poljoprivredni zaposlenici, ESeG7-manje kvalificirani radnici, ESeG8-umirovljenici, ESeG9-ostale nezaposlene osobe. U svrhu analize u ovom članku koristili smo varijantu troklasne sheme (ESeG $1+2=$ viša klasa-salarijat; ESeG 3+4+5=srednja klasa; ESeG 6+7=radnička klasa). ESeG8 skupina umirovljenika prema zadnjem je zaposlenju uvrštena u troklasnu klasnu shemu te se po potrebi može koristiti u analizi, no u ovom radu zbog analitičkih potreba koristimo troklasnu shemu koja ne uključuje umirovljenike. 
Indikator radnog statusa korišten je s odgovorima (1) radi kao zaposlenik/ica, (2) nezaposlen/a, (3) trajno nesposoban/na za rad (zbog dugotrajne bolesti ili invaliditeta), (4) umirovljenik/ica, (5) školuje se / student. Ispitanici koji su zaposleni bili su upitani rade li u javnom ili privatnom sektoru.

Kao indikator procjene smanjenja prihoda zbog pandemije korišteno je pitanje koje je glasilo: „Kako je kriza izazvana epidemijom koronavirusa utjecala na ukupne prihode Vas i Vašeg kućanstva?“. Ispitanici su mogli odabrati jedan od sljedećih odgovora: (1) znatno su smanjeni, (2) nešto su smanjeni, (3) ostali su na sličnoj razini, (4) nešto su se povećali, (5) znatno su se povećali.

Iskustvo gubitka posla zbog pandemije indikator je koji je konstruiran iz dva pitanja o dobivanju otkaza zbog ekonomskih posljedica epidemije koronavirusa, pri čemu je jedno pitanje bilo usmjereno na ispitanika/icu, dok je drugo pitanje usmjereno na člana/članove kućanstva.

Ispitanici su odgovarali i na pitanje oko ukupnih obiteljskih mjesečnih prihoda, uključujući osobne dohotke, mirovine, dječje doplatke, naknade za nezaposlene, socijalnu pomoć, naknade od osiguranja, rentu, autorske honorare, novac koji im netko osobno daje, prihode od iznajmljivanja i sve ostale izvore prihoda (nakon odbijanja poreza).

Korišten je i indikator obrazovanja koji je rekodiran na tri razine obrazovanja (primarna, sekundarna i tercijarna). Uz obrazovanje ispitanici su procjenjivali razinu povjerenja u Nacionalni stožer civilne zaštite u pogledu upravljanja krizom uzrokovanom epidemijom koronavirusa, u znanstvenike-istraživače da mogu pronaći lijek ili cjepivo za bolest izazvanu koronavirusom, u medije u pogledu objektivnog izvještavanja o krizi uzrokovanoj epidemijom koronavirusa, u Vladu RH u pogledu upravljanja krizom uzrokovanom epidemijom koronavirusa te u zdravstveni sustav RH u pogledu upravljanja krizom uzrokovanom epidemijom koronavirusa. Ispitanici su mogli izabrati jedan od četiriju odgovora: (1) uopće nemam povjerenje, (2) uglavnom nemam povjerenje, (3) uglavnom imam povjerenje, (4) imam puno povjerenje. Za potrebe analize konstruiran je aditivni Indeks povjerenja u stožer, znanstvenike, medije, Vladu $\mathrm{RH}$ i zdravstveni sustav. Raspon je indeksa od 5 do 20 , pri čemu više vrijednosti označavaju višu razinu povjerenja $(\mathrm{M}=13,9 ; \mathrm{sd}=3,63)$.

Kao indikator političke identifikacije korišteno je pitanje o glasanju na posljednjim izborima (srpanj 2020. godine), na kojem su ispitanici odgovarali za koje političke stranke/koalicije su glasali. Pitanje je rekodirano u odgovore: (1) apstinenti, (2) desno (Domovinski pokret, Most), (3) desni centar (HDZ), (4) centar (Fokus, Stranka s imenom i prezimenom, Pametno), (5) lijevi centar (RESTART koalicija), (6) ljevica (Možemo! - politička platforma), (7) bez odgovora. 
Kao pandemijski kontekstualni indikatori korištena su dva pitanja. Jedno se odnosi na negativan utjecaj na zdravlje, pri čemu su ispitanici pitani smatraju li da je epidemija koronavirusa negativno utjecala na njihovo zdravlje (odgovori: (1) nije imala zamjetan negativan utjecaj, (2) imala je manji negativan utjecaj, (3) imala je značajan negativan utjecaj). Drugo pitanje odnosi se na procjenu trenutne situacije, u kojem su ispitanici upitani kako osobno doživljavaju trenutnu situaciju i život u okolnostima epidemije. Odgovori su bili (1) potpuno bezizlazna; (2) kritična, na trenutke kaotična; (3) neugodna, umarajuća; (4) podnošljiva, ide nekako; (5) normalna, s obzirom na okolnosti; (6) potpuno normalna, kao što je bila i prije pojave koronavirusa.

U analizi su korištene univarijatne, bivarijatne i multivarijatne statističke analize, dok su podaci statistički obrađivani i analizirani u statističkom paketu SPSS (IBM SPSS Statistics 20).

\section{Rezultati}

U grafikonu 1 prikazana je distribucija ispitanika prema procjeni opasnosti koronavirusa i adekvatnosti epidemioloških mjera kao indirektna mjera antimaskerske reakcije u hrvatskom društvu i procjena veličine bazena iz kojeg se regrutiraju oni koji su podržavali antimaskerske prosvjede organizirane tijekom 2020. godine. Treba naglasiti kako velika većina u hrvatskom društvu (87\%) prepoznaje opasnost od bolesti COVID-19 i smatra da bi posljedice mogle biti kobne, dok oko 13\% umanjuje opasnost od te bolesti i smatra da su mjere prestroge. Od toga nešto malo manje od 3\% ispitanika smatra da SARS-CoV-2 zapravo i ne postoji, te u tom smislu u potpunosti negira realnu opasnost od pandemije. Kako bismo istražili je li instrument za procjenu antimaskerskog impulsa u društvu koji smo kreirali adekvatan, analizirali smo i razlike između te četiri kategorije odgovora i indeksa nepoštivanja epidemioloških mjera.

\section{Grafikon 1.}

Procjena opasnosti korona virusa i procjena primjerenosti mjera na snazi (\%).

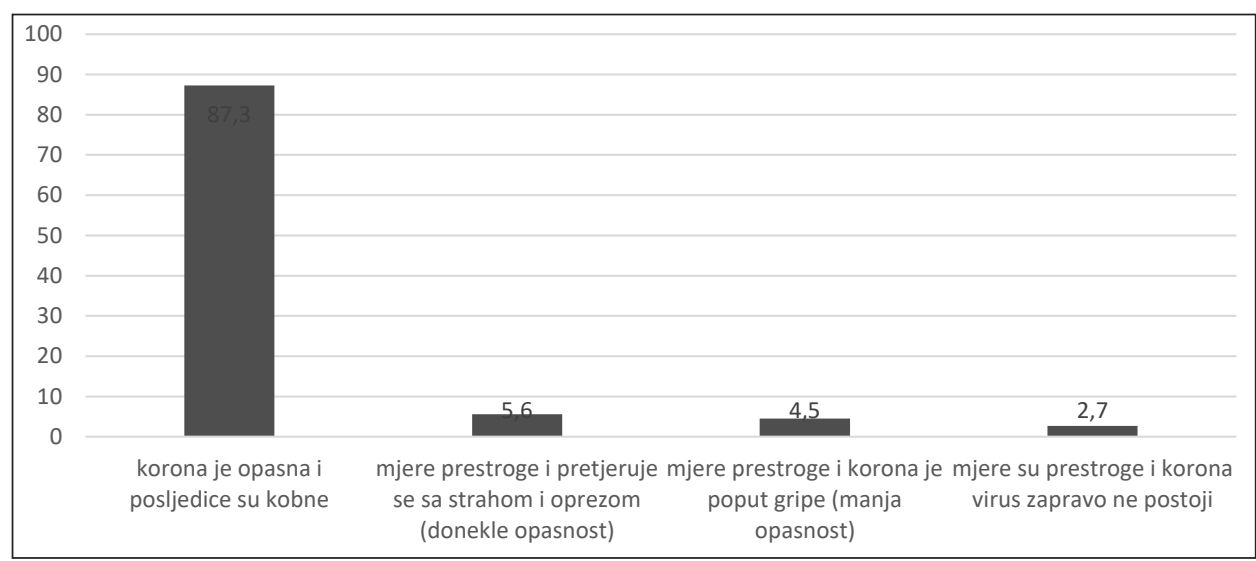


Očekivano, post hoc testiranje u analizi varijance pokazuje kako se u najvećoj mjeri epidemioloških mjera pridržavaju oni ispitanici koji prepoznaju opasnosti od zaraze koronavirusom $(\mathrm{M}=2,15)$. I kao takvi se razlikuju od onih koji misle da su mjere prestroge i da se pretjeruje sa strahom i oprezom $(\mathrm{M}=3,78)$ ili da je koronavirus poput gripe $(M=4,34)$, dakle skupina ispitanika koje se pak međusobno ne razlikuju u nepoštivanju epidemioloških mjera. Na drugom se kraju nalaze oni koji ne vjeruju u postojanje koronavirusa i razlikuju se od prvih triju grupa, te se kao takvi većine epidemioloških mjera ne pridržavaju $(M=6,19)$.

Grafikon 2.

Mjere antimaskerstva i indeks nepoštivanja epidemioloških mjera.

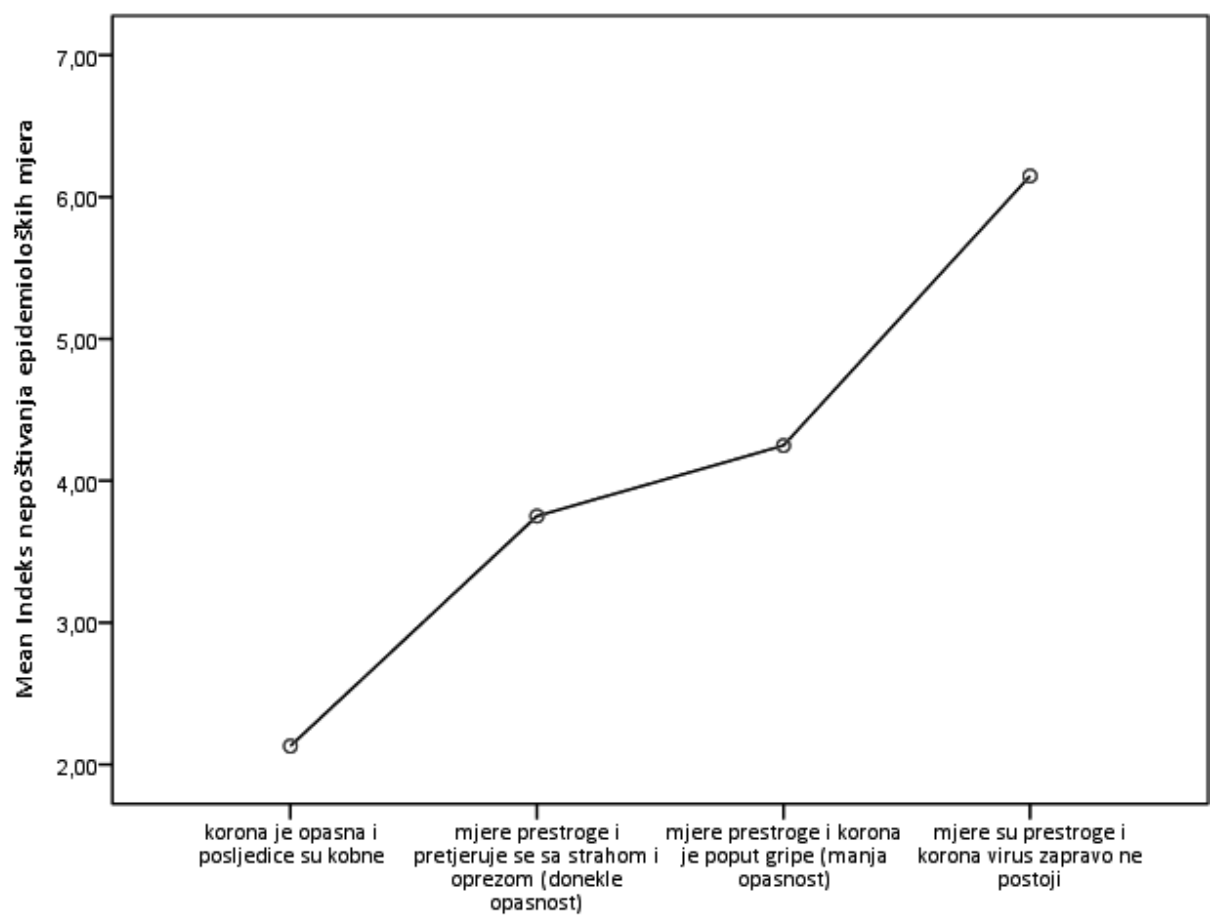

Na temelju tih nalaza, smatramo da je opravdano prvu skupinu ispitanika - onih ljudi koji prepoznaju opasnost oko zaraze koronavirusom i smatraju mjere ili primjerenima ili čak preblagima - klasificirati kao one koji se nastoje pridržavati većine epidemioloških mjera, odnosno kao one koji nisu antimaskeri. Nadalje, $s$ obzirom na to da ostale tri skupine umanjuju opasnost od koronavirusa, smatraju da su mjere prestroge te pokazuju značajno manju sklonost pridržavanju epidemioloških mjera, smatramo da ih je u kontekstu društvenih reakcija uslijed pandemije COVID-19 opravdano klasificirati kao antimaskere. Shodno tome u daljnjoj ćemo ih analizi promatrati u toj dihotomnoj distinkciji. 
Tablica 1.

Neke sociodemografske karakteristike antimaskera.

\begin{tabular}{|c|c|c|c|c|}
\hline & & Nisu antimaskeri & Antimaskeri & Testirane razlike \\
\hline \multirow{2}{*}{ Spol } & $M(N=720)$ & $85,30 \%$ & $14,70 \%$ & \multirow{2}{*}{$\begin{array}{c}F=19,627 \\
P<, 001\end{array}$} \\
\hline & $\check{Z}(N=723)$ & $89,00 \%$ & $11,00 \%$ & \\
\hline \multirow{5}{*}{ Dob } & $18-29(\mathrm{~N}=259)$ & $82,20 \%$ & $17,80 \%$ & \multirow{5}{*}{$\begin{array}{c}\chi 2=64,705 \\
p=0,001\end{array}$} \\
\hline & $30-39(\mathrm{~N}=249)$ & $76,30 \%$ & $23,70 \%$ & \\
\hline & $40-49(N=256)$ & $85,50 \%$ & $14,50 \%$ & \\
\hline & $50-64(\mathrm{~N}=409)$ & $90,50 \%$ & $9,50 \%$ & \\
\hline & $65+(N=338)$ & $96,70 \%$ & $3,30 \%$ & \\
\hline \multirow{3}{*}{$\begin{array}{l}\text { Broj osoba } \\
\text { starijih od } 65 \\
\text { u kućanstvu }\end{array}$} & $0(\mathrm{~N}=1062)$ & $85,70 \%$ & $14,30 \%$ & \multirow{3}{*}{$\begin{array}{c}\chi 2=8,524 ; \\
p=0,014\end{array}$} \\
\hline & $1(\mathrm{~N}=373)$ & $91,40 \%$ & $8,60 \%$ & \\
\hline & $2(\mathrm{~N}=76)$ & $89,50 \%$ & $10,50 \%$ & \\
\hline
\end{tabular}

U tablici 1 prikazani su postotni udjeli (anti)maskera s obzirom na spol, dob te broj osoba starijih od 65 godina života u kućanstvu. Testirane razlike pokazuju kako je antimaskera nešto više među muškarcima nego među ženama, među osobama mlađe životne dobi (poglavito među onima između 30 i 39 godina) te među onima koji žive u kućanstvima u kojima ne žive osobe starije od 65 godina.

Testirane su i razlike prema regijama (Dalmacija, Istra i Primorje sa zaleđem, Zagreb, Sjeverna Hrvatska, Središnja Hrvatska i Slavonija) i pokazuje se kako ne postoje statistički značajne razlike u udjelu antimaskera.

S obzirom na to da neka od spomenutih istraživanja upućuju na povezanost niže obrazovne razine sa sklonošću alternativnim narativima, analizirali smo prisutnost antimaskerske reakcije prema završenom stupnju obrazovanja (tablica 3). Testirana razlika upućuje na zaključak kako je udio antimaskera prisutniji na sekundarnoj i tercijarnoj razini obrazovanja nego što je na primarnoj razini. Dakle, pokazuje se kako, suprotno očekivanjima koja proizlaze iz istraživanja povezanosti obrazovanja i sklonosti teorijama zavjera, obrazovanje u ovoj analizi ima suprotan efekt - viša razina obrazovanja, veća prisutnost antimaskerske reakcije.

Tablica 2.

\begin{tabular}{|c|c|c|c|c|}
\hline & & Nisu antimaskeri & Antimaskeri & Testirane razlike \\
\hline \multirow{3}{*}{ Obrazovanje } & Primarna razina $(\mathrm{N}=385)$ & $94,0 \%$ & $6,0 \%$ & \multirow{3}{*}{$\begin{array}{c}\chi^{2}=21,636 \\
p<0,001\end{array}$} \\
\hline & Sekundarna razina $(\mathrm{N}=833)$ & $84,5 \%$ & $15,5 \%$ & \\
\hline & Tercijarna razina $(\mathrm{N}=294)$ & $86,4 \%$ & $13,6 \%$ & \\
\hline
\end{tabular}


Budući da dosadašnja istraživanja i teorijski pristup sugeriraju kako su ljudi skloniji više vjerovati alternativnim narativima i negirati realnost $\mathrm{u}$ onim društvenim situacijama kada imaju osjećaj da im prijeti egzistencijalna nesigurnost i kad im je mogućnost zadovoljavanja egzistencijalnih potreba ugrožena, analizirali smo pojavu antimaskerske reakcije u odnosu s indikatorima egzistencijalnih uvjeta (klasna struktura, radni status, prihodi, rad u javnom/privatnom sektoru) i indikatora koji upućuju na promjene uzrokovane pandemijom COVID-19 (procjena smanjenja prihoda, gubitak posla).

Tablica 3.

Indikatori egzistencijalnih uvjeta i antimaskerstvo.

\begin{tabular}{|c|c|c|c|c|}
\hline & & $\begin{array}{l}\text { Nisu } \\
\text { antimaskeri }\end{array}$ & Antimaskeri & $\begin{array}{l}\text { Testirane } \\
\text { razlike }\end{array}$ \\
\hline \multirow{3}{*}{$\begin{array}{l}\text { ESeG (bez } \\
\text { umirovljenika) }\end{array}$} & Viša klasa - salarijat $(\mathrm{N}=132)$ & $86,4 \%$ & $13,6 \%$ & \multirow{3}{*}{$\begin{array}{c}\chi 2=14,954 \\
p=0,001\end{array}$} \\
\hline & Srednja klasa $(\mathrm{N}=201)$ & $88,1 \%$ & $11,9 \%$ & \\
\hline & Radnička klasa $(\mathrm{N}=230)$ & $74,8 \%$ & $25,2 \%$ & \\
\hline \multirow{6}{*}{ Radni status } & Umirovljenik ( $\mathrm{N}=491)$ & $94,7 \%$ & $5,3 \%$ & \multirow{6}{*}{$\begin{array}{c}\chi 2=55,821 \\
p<0,001\end{array}$} \\
\hline & Zaposleni $(\mathrm{N}=642)$ & $81,6 \%$ & $18,4 \%$ & \\
\hline & Nezaposleni $(\mathrm{N}=157)$ & $79,6 \%$ & $20,4 \%$ & \\
\hline & Učenik ili student ( $\mathrm{N}=133$ ) & $92,5 \%$ & $7,5 \%$ & \\
\hline & $\begin{array}{l}\text { Radim u kućanstvu i na kućanskim poslovima, } \\
\text { brinem o djeci i/ili o drugim osobama }(\mathrm{N}=72)\end{array}$ & $91,7 \%$ & $8,3 \%$ & \\
\hline & $\begin{array}{l}\text { Trajno nesposoban/na za rad (zbog } \\
\text { dugotrajne bolesti ili invaliditeta) }(\mathrm{N}=14)\end{array}$ & $92,9 \%$ & $7,1 \%$ & \\
\hline \multirow{2}{*}{$\begin{array}{l}\text { Rad u privatnom } \\
\text { ili javnom } \\
\text { sektoru }\end{array}$} & Javni sektor $(\mathrm{N}=237)$ & $87,8 \%$ & $12,2 \%$ & \multirow{2}{*}{$\begin{array}{c}\chi 2=9,724 \\
p<0,002\end{array}$} \\
\hline & Privatni sektor $(\mathrm{N}=397)$ & $77,8 \%$ & $22,2 \%$ & \\
\hline \multirow{5}{*}{$\begin{array}{l}\text { Procjena } \\
\text { smanjenja } \\
\text { prihoda zbog } \\
\text { pandemije }\end{array}$} & Znatno su smanjeni ( $\mathrm{N}=161)$ & $83,2 \%$ & $16,8 \%$ & \multirow{5}{*}{$\begin{array}{c}\chi 2=13,093 \\
p<0,011\end{array}$} \\
\hline & Nešto su smanjeni (N=297) & $82,5 \%$ & $17,5 \%$ & \\
\hline & Ostali su na sličnoj razini (N=993) & $88,9 \%$ & $11,1 \%$ & \\
\hline & Nešto su se povećali $(\mathrm{N}=58)$ & $93,1 \%$ & $6,9 \%$ & \\
\hline & Znatno su se povećali $(\mathrm{N}=3)$ & $100,0 \%$ & $0,0 \%$ & \\
\hline \multirow{2}{*}{$\begin{array}{l}\text { Iskustvo gubitka } \\
\text { posla zbog } \\
\text { pandemije }\end{array}$} & $\mathrm{Ne}(\mathrm{N}=1460)$ & $87,7 \%$ & $12,3 \%$ & \multirow{2}{*}{$\begin{array}{c}\chi 2=9,208 \\
p<0,002\end{array}$} \\
\hline & $\mathrm{Da}(\mathrm{N}=53)$ & $73,6 \%$ & $26,4 \%$ & \\
\hline \multirow{2}{*}{ Prihod kućanstva } & M (HRK) & 9097,39 & 10016,05 & \multirow{2}{*}{$\begin{array}{l}F=, 014 \\
p=, 905\end{array}$} \\
\hline & S.D. & 6238,43 & 5596,91 & \\
\hline
\end{tabular}

5 Uključuje sve državne i javne službe, kao i javna poduzeća koja su barem $50 \%$ u vlasništvu države. 
Iz perspektive klasne strukture društva pokazuje se kako kada se koristi klasni indikator (bez uključenih umirovljenika $\mathrm{u}$ analizi) postoje razlike $s$ obzirom na antimaskersku reakciju, i to na način da su antimaskeri, kada se međusobno usporede tri klase u analizi, nadzastupljeni unutar radničke klase (25\%). Razlike postoje i s obzirom na radni status ispitanika. Ako se pogledaju razlike između različitih radnih statusa, vidljivo je kako su antimaskeri u najvećoj mjeri prisutni upravo u kontingentu radno aktivnog dijela populacije (zaposleni i nezaposleni). Ako je udio antimaskera u općoj populaciji oko $13 \%$, onda udio od oko $18 \%$ kod zaposlenih i od oko $20 \%$ kod nezaposlenih upućuje na efekt tržišta rada na antimaskersku društvenu reakciju. U prilog tomu ide i analizirana razlika prema radu podijeljenom u javni i privatni sektor. Razlika upućuje na to da antimaskera ima dvostruko više unutar onih ispitanika koji rade u privatnom sektoru naspram onih koji rade u javnom sektoru.

Iz analize nije vidljivo da se antimaskerska reakcija ispitanika razlikuje s obzirom na prihode kućanstva, no razlika je prisutna ukoliko su se prihodi smanjivali zbog pandemije COVID-19. Kod onih ispitanika kod kojih su se kućanski prihodi ili značajno smanjili ili se nešto smanjili zabilježena je nešto veća prisutnost antimaskerske reakcije. Isto je i kod onih kućanstava u kojima je zabilježen gubitak posla zbog pandemije.

U kontekstu istraživanja povjerenja i antimaskerske reakcije analizirali smo razlike u povjerenju prema Nacionalnom stožeru civilne zaštite u pogledu upravljanju krizom, u znanstvenike da mogu pronaći lijek ili cjepivo za bolest, u medije u pogledu objektivnog izvještavanja o krizi uzrokovanom epidemijom koronavirusa, u Vladu RH u pogledu upravljanja krizom uzrokovanom epidemijom koronavirusa te u zdravstveni sustav RH u pogledu nošenja s krizom uzrokovanom epidemijom koronavirusa.

Tablica 4.

Institucionalno povjerenje i antimaskerstvo

\begin{tabular}{|c|c|c|c|c|}
\hline & & $\begin{array}{c}\mathrm{Nisu} \\
\text { antimaskeri }\end{array}$ & Antimaskeri & $\begin{array}{l}\text { Testirane } \\
\text { razlike }\end{array}$ \\
\hline \multirow{2}{*}{$\begin{array}{l}\text { Povjerenje u Nacionalni stožer civilne zaštite u pogledu } \\
\text { upravljanja krizom }\end{array}$} & M & 2,91 & 1,79 & \multirow{2}{*}{$\begin{array}{l}t=14,757 ; \\
p<0,001\end{array}$} \\
\hline & S.D. & ,967 & 975 & \\
\hline \multirow{2}{*}{$\begin{array}{l}\text { Povjerenje u znanstvenike da mogu pronaći lijek ili } \\
\text { cjepivo za bolest }\end{array}$} & $M$ & 3,29 & 2,63 & \multirow{2}{*}{$\begin{array}{c}t=10,038 ; \\
p<0,001\end{array}$} \\
\hline & S.D. & ,796 & 1,1 & \\
\hline \multirow{2}{*}{$\begin{array}{l}\text { Povjerenje u medije u pogledu objektivnog izvještavanja } \\
\text { o krizi uzrokovanom epidemijom koronavirusa }\end{array}$} & $M$ & 2,51 & 1,73 & \multirow{2}{*}{$\begin{array}{l}t=10,610 ; \\
p<0,001\end{array}$} \\
\hline & S.D. & 960 & ,843 & \\
\hline \multirow{2}{*}{$\begin{array}{l}\text { Povjerenje U Vladu RH u pogledu upravljanja krizom } \\
\text { uzrokovanom epidemijom koronavirusa }\end{array}$} & $M$ & 2,59 & 1,78 & \multirow{2}{*}{$\begin{array}{l}t=10,308 ; \\
p<0,001\end{array}$} \\
\hline & S.D. & 1,027 & ,982 & \\
\hline \multirow{2}{*}{$\begin{array}{l}\text { Povjerenje u zdravstveni sustav RH u pogledu nošenja s } \\
\text { krizom uzrokovanom epidemijom koronavirusa }\end{array}$} & $M$ & 3,15 & 2,46 & \multirow{2}{*}{$\begin{array}{l}t=10,128 ; \\
p<0,001\end{array}$} \\
\hline & S.D. & 836 & 1,016 & \\
\hline
\end{tabular}

Skala: 1 - uopće nemam povjerenje, 4 -imam puno povjerenja. 
T-test pokazuje kako postoji statistički značajna razlika između antimaskera i onih koji nisu antimaskeri prema svim mjerenim razinama društvenog povjerenja u kontekstu pandemije COVID-19. Antimaskeri iskazuju veće nepovjerenje prema svim segmentima društvenih institucija i sektora relevantnih za nošenje s pandemijom. Najveće nepovjerenje antimaskeri iskazuju prema medijima u pogledu objektivnog izvještavanja o krizi uzrokovanoj bolešću COVID-19 te prema Vladi RH i Nacionalnom stožeru civilne zaštite u pogledu upravljanja krizom. Manju razinu nepovjerenja iskazuju prema znanstvenicima da mogu pronaći lijek ili cjepivo za virus SAR-CoV-2 te prema zdravstvenom sustavu RH u pogledu nošenja s krizom.

Na kraju, literatura upućuje na povezanost zastupanja teorija zavjere i političkih stavova, prvenstveno vezanih za radikalne političke opcije. Kako bismo mogli otkriti nešto o identitetskim obilježjima antimaskerstva, analizirali smo postoji li razlika između antimaskera i onih koji to nisu u pogledu stranačkih preferencija na posljednjim parlamentarnim izborima.

Grafikon 3.

Stranačke preferencije antimaskera.

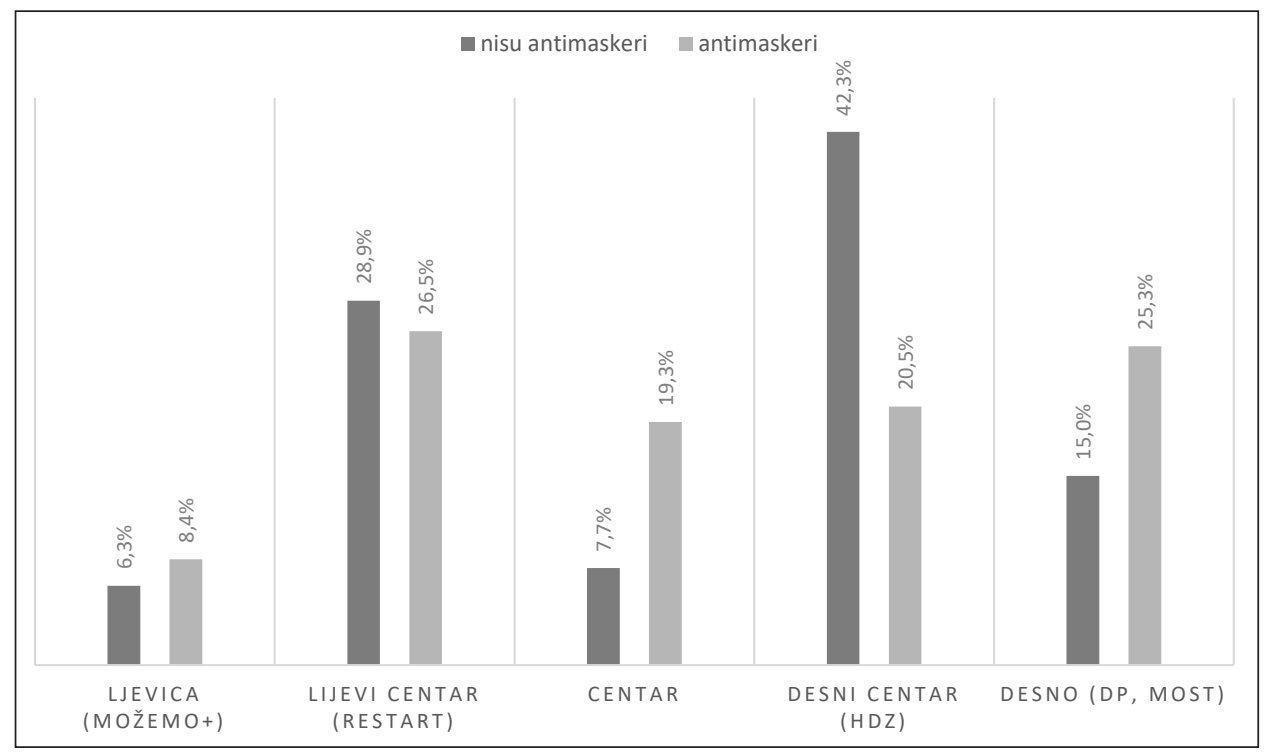

Povezanost političkih preferencija i sklonosti teorijama zavjera donekle se potvrđuje u našim podacima. Testirana razlika pokazuje kako se antimaskeri i oni koji to nisu statistički značajno razlikuju s obzirom na to za koga su glasali na parlamentarnim izborima u srpnju 2020. godine $(\chi 2=24,895 ; \mathrm{p}<0,001)$. Razlike su evidentne na desnom dijelu političkog spektra, budući da antimaskere možemo pronaći više među biračima stranaka krajnje desnice poput Domovinskog pokreta i Mosta. S druge strane, ono što se manje uklapa u podatke iz literature frekvencija je antimaskera među biračima stra- 
naka centra poput Pametno, Stranke s imenom i prezimenom i Fokusa, neke od kojih jaki fokus stavljaju na znanstvenu racionalnost, potporu sustavu znanosti i sl. Na lijevom dijelu političkog spektra razlike nisu toliko izražene. Zanimljivo je da najmanje antimaskera ima među biračima HDZ-a, koji okuplja desni centar do krajnje desnice.

\subsection{Determinante antimaskerske reakcije}

U tablici 5 nalaze se koeficijenti i značajnosti binarnog logističkog regresijskog modeliranja antimaskerske reakcije (kriterijska varijabla) kako bi se testirao efekt sociodemografskih karakteristika (spol, dob, obrazovanje, struktura kućanstva prema broju osoba starijih od 65 godina), egzistencijalnih uvjeta (klasne razlike, radni status, rad u privatnom/javnom sektoru, procjena smanjenja prihoda, iskustvo gubitka posla zbog pandemije COVID-19, prihodi kućanstva), društvenog povjerenja, konteksta pandemijske situacije (negativan utjecaj cjelokupne situacije na zdravlje, doživljaj cjelokupne situacije) te preferencije političkih stranaka. U kriterijskoj varijabli (indikator antimaskerske reakcije) referentna je vrijednost 1 , odnosno sklonost antimaskerstvu. Za svaki od prediktora referentna je vrijednost označena u tablici 5 . U prediktorskom sklopu sve su varijable tretirane kao kvalitativne, osim Indeksa povjerenja, koji uključuje povjerenje u Nacionalni stožer, znanstvenike, medije, Vladu RH i zdravstveni sustav. 


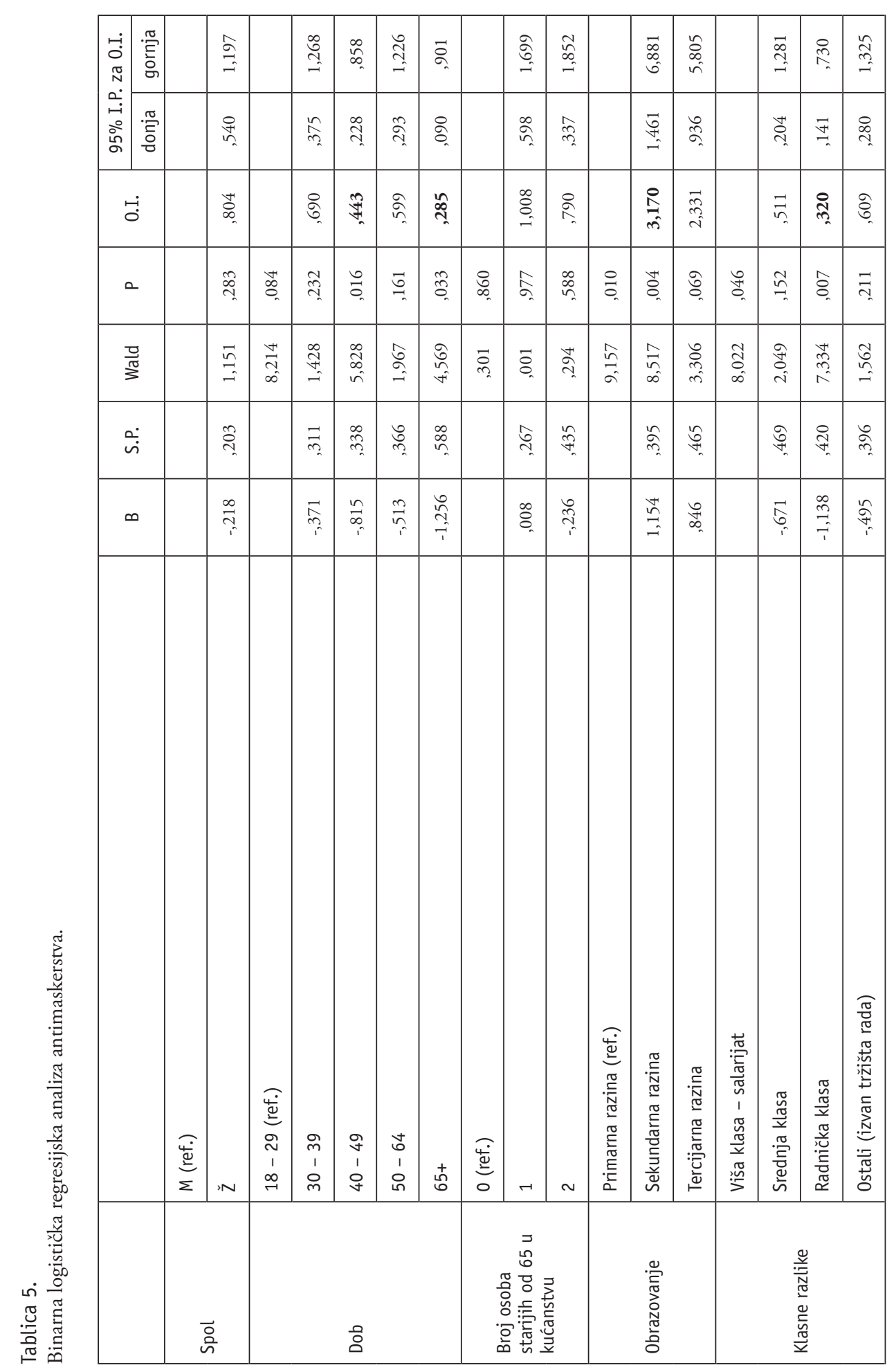




\begin{tabular}{|c|c|c|c|c|c|c|c|c|c|c|c|c|c|c|c|c|c|c|c|c|c|}
\hline & $\begin{array}{l}\hat{n} \\
\hat{n}\end{array}$ & $\begin{array}{l}\approx \\
\infty \\
-0 \\
\rightarrow\end{array}$ & $\underset{+}{\stackrel{+}{r}}$ & 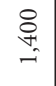 & 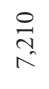 & & 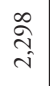 & & $\begin{array}{l}\hat{\hat{\lambda}} \\
\hat{i}\end{array}$ & $\stackrel{\stackrel{\leftrightarrow}{n}}{\stackrel{2}{=}}$ & $\stackrel{m}{\stackrel{m}{=}}$ & & & $\underset{\text { ते }}{\stackrel{\text { ñ }}{2}}$ & & 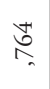 & $\stackrel{N}{N}$ & $\begin{array}{l}\stackrel{\hat{O}}{=} \\
\approx\end{array}$ & $\stackrel{\Delta}{\sigma}$ & $\hat{\approx}$ & $\stackrel{*}{n}$ \\
\hline & $\stackrel{\curvearrowright}{\underset{\sigma}{\sigma}}$ & 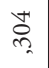 & $\hat{E}$ & $\overrightarrow{8}$ & ర్రి & & $\stackrel{\hat{n}}{n}$ & & 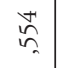 & ळे & 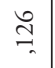 & 8 & & $\vec{\sigma}$ & & $\stackrel{\infty}{\underset{士}{\leftrightarrows}}$ & $\stackrel{\vartheta}{=}$ & 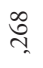 & $\stackrel{\infty}{\rightleftharpoons}$ & $\stackrel{\sim}{\approx}$ & $\vec{b}$ \\
\hline & $\overrightarrow{\mathrm{b}}$ & 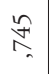 & ิે & ปิ & $\begin{array}{l}\stackrel{0}{2} \\
m\end{array}$ & & $\overrightarrow{\widetilde{\widetilde{\sigma}}}$ & & $\begin{array}{l}\stackrel{\infty}{\simeq} \\
= \\
=\end{array}$ & 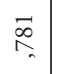 & $\underset{+}{\stackrel{\leftrightarrow}{+}}$ & 8 & & $\underset{\Im}{\mathbb{Z}}$ & & ల్ల & ले & ฉิ & $\stackrel{\approx}{\approx}$ & ఫ్ & $\stackrel{\gtrless}{\circledR}$ \\
\hline$\hat{\tilde{\sigma}}$ & $\tilde{n}$ & $\stackrel{\sim}{\sim}$ & $\stackrel{\vec{H}}{\sigma_{0}}$ & $\stackrel{\vec{J}}{\underset{J}{*}}$ & $\overrightarrow{\tilde{n}}$ & & $\stackrel{\approx}{\approx}$ & 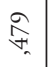 & $\stackrel{\circ}{\stackrel{1}{1}}$ & $\stackrel{+r}{\stackrel{+}{*}}$ & 足 & 亏े & & $\vec{F}$ & $\stackrel{0}{\infty}$ & ळे & $\stackrel{\circ}{\circ}$ & $\vec{I}$ & $\stackrel{\infty}{\widetilde{\delta}}$ & $\tilde{\delta}$ & 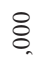 \\
\hline$\stackrel{\vec{n}}{\rightrightarrows=}$ & $\stackrel{n}{n}$ & $\stackrel{n}{F_{n}}$ & $\begin{array}{l}\hat{\sigma} \\
\hat{\sigma}\end{array}$ & $\begin{array}{l}\hat{\mathrm{O}} \\
\mathrm{i} \\
\hat{i}\end{array}$ & $\stackrel{\ominus}{\underset{\forall}{*}}$ & & $\stackrel{\infty}{2}$ & 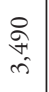 & $\fallingdotseq$ & $\stackrel{\varpi}{\sim}$ & $\begin{array}{l}\tilde{n} \\
\tilde{\sigma} \\
-\end{array}$ & ठ̊. & & $\stackrel{0}{6}$ & $\begin{array}{l}\stackrel{\Xi}{\circ} \\
\stackrel{2}{a}\end{array}$ & $\underset{\sigma}{\stackrel{N}{N}}$ & $\begin{array}{l}\text { :্+ } \\
\text { G }\end{array}$ & $\begin{array}{l}\hat{\sigma} \\
\hat{i}\end{array}$ & $\underset{\overbrace{}}{\stackrel{\widehat{\sigma}}{f}}$ & \begin{tabular}{l}
$\overrightarrow{\tilde{n}}$ \\
\multirow{f}{*}{}
\end{tabular} & $\begin{array}{l}\text { के } \\
\text { हे }\end{array}$ \\
\hline & $\stackrel{\infty}{\sim}$ & $\hat{f}_{n}$ & $\begin{array}{l}\infty \\
\stackrel{\infty}{n}\end{array}$ & $\begin{array}{l}8 \\
\infty \\
\infty\end{array}$ & $\begin{array}{l}\text { 今ै } \\
\stackrel{n}{-}\end{array}$ & & $\begin{array}{l}\infty \\
\stackrel{\infty}{\sim}\end{array}$ & & $\begin{array}{l}\tilde{0} \\
\tilde{n}\end{array}$ & 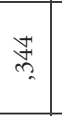 & $\hat{\mathrm{o}}$ & 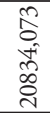 & & ఫ్ & & $\overrightarrow{\vec{\nabla}}$ & $\overrightarrow{\vec{F}_{n}}$ & $\stackrel{n}{n}$ & ळे & $\begin{array}{l}2 \\
\cdots\end{array}$ & 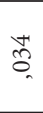 \\
\hline & $\stackrel{\infty}{\circ}$ & 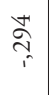 & 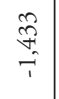 & 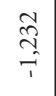 & $\stackrel{\infty}{\circ}$ & & $\stackrel{\infty}{\stackrel{\infty}{y}}$ & & $\stackrel{\overbrace{}}{\beth}$ & 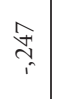 & $\stackrel{m}{\stackrel{2}{i}}$ & $\begin{array}{l}\underset{\sim}{\sim} \\
\underset{\sim}{\sim}\end{array}$ & & กิ & & $\begin{array}{l}\overrightarrow{\widehat{\sigma}} \\
\vec{i}\end{array}$ & $\begin{array}{l}\overrightarrow{0} \\
\stackrel{-}{i} \\
\vec{i}\end{array}$ & 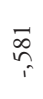 & $\begin{array}{l}n \\
\hat{\infty} \\
i \\
i\end{array}$ & $\overrightarrow{0}$ & $\stackrel{\infty}{\stackrel{\infty}{+}}$ \\
\hline 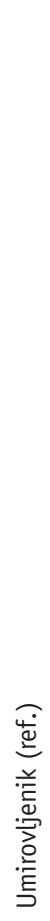 & 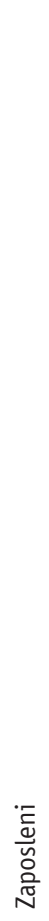 & 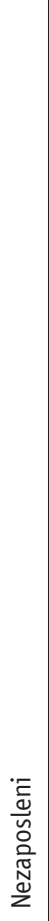 & 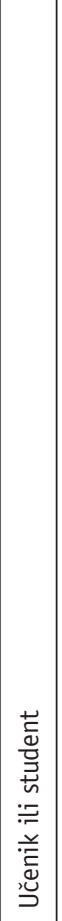 & 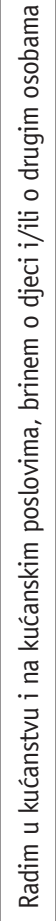 & 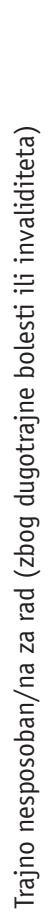 & 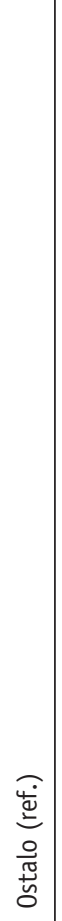 & 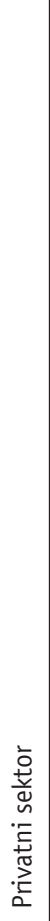 & 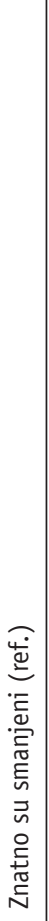 & 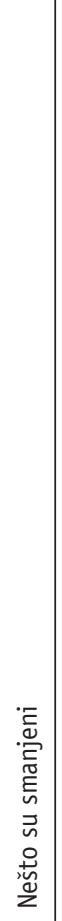 & 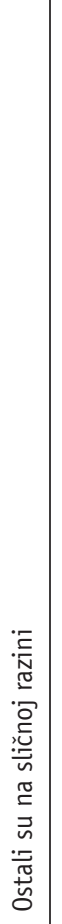 & 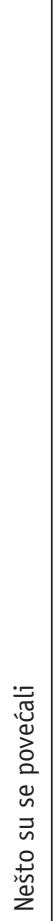 & 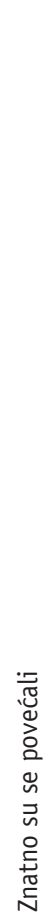 & 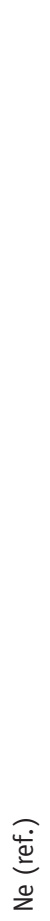 & $\tilde{a}$ & 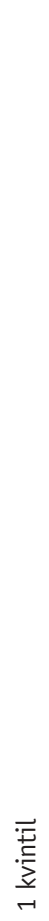 & 胥 & 吾 & 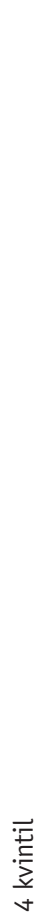 & 吾 & 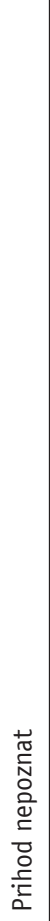 & 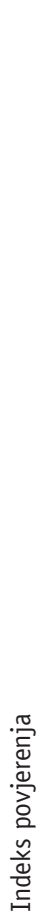 \\
\hline \multicolumn{6}{|c|}{ 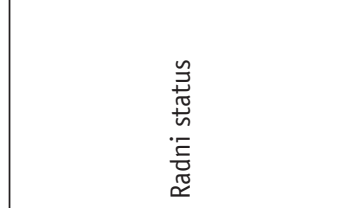 } & 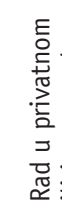 & & \multicolumn{5}{|c|}{ 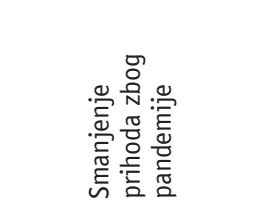 } & \multicolumn{2}{|c|}{ 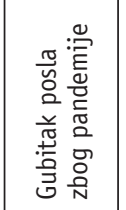 } & 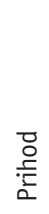 & & & & & & 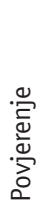 \\
\hline
\end{tabular}




\begin{tabular}{|c|c|c|c|c|c|c|c|c|c|c|c|c|c|c|c|c|c|}
\hline & $\stackrel{n}{\hat{n}}$ & $\stackrel{\sigma}{\sigma}$ & & 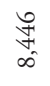 & 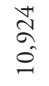 & $\stackrel{\text { ڤ̆ }}{\wedge}$ & 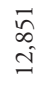 & $\begin{array}{l}\overrightarrow{\widetilde{N}} \\
\hat{\tilde{n}}\end{array}$ & & $\stackrel{\infty}{\stackrel{\infty}{\rightarrow}}$ & $\begin{array}{l}\stackrel{m}{i n} \\
\stackrel{i}{i}\end{array}$ & $\begin{array}{l}\overrightarrow{\vec{s}} \\
\vec{i}\end{array}$ & $\begin{array}{l}\text { oे } \\
\text { nं }\end{array}$ & 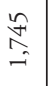 & $\begin{array}{l}\text { సे } \\
\text { ते }\end{array}$ & & \\
\hline & $\stackrel{\grave{n}}{\sim}$ & 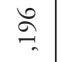 & & है & 今े & ֻे & है & 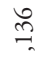 & & $\underset{f}{\stackrel{尺}{f}}$ & 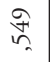 & $\vec{\sigma}$ & $\stackrel{\Re}{\stackrel{n}{n}}$ & \begin{tabular}{l}
$\stackrel{0}{*}$ \\
\multirow{\sigma}{*}{}
\end{tabular} & $\stackrel{\cong}{\underset{F}{*}}$ & & \\
\hline & $\underset{\infty}{\stackrel{W}{\infty}}$ & $\mathbb{*}$ & & ڤ్ & $\underset{\nabla}{\stackrel{\sharp}{R}}$ & $\overrightarrow{\vec{n}}$ & $\underset{\infty}{\sharp}$ & $\begin{array}{l}\hat{\hat{v}} \\
\hat{i}\end{array}$ & & $\overrightarrow{\overrightarrow{D_{n}}}$ & $\stackrel{\Xi}{\stackrel{\Xi}{=}}$ & $\stackrel{\underset{\sim}{\tilde{N}}}{=}$ & $\hat{\widehat{G}}$ & $\widetilde{\infty_{\sigma}}$ & $\begin{array}{l}\tilde{O} \\
=\end{array}$ & & \\
\hline$\stackrel{\infty}{\simeq}$ & ๙े & $\stackrel{0}{n}$ & $\hat{\tilde{o}}$ & 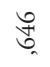 & ळे & $\overrightarrow{\widehat{\sigma}}$ & $\begin{array}{l}\stackrel{+}{\infty} \\
\infty \\
\infty\end{array}$ & $\stackrel{R}{n}$ & $\approx$ & $\underset{F}{F}$ & $\underset{\tilde{O}}{\tilde{O}}$ & $\hat{n}$ & $\widetilde{\widetilde{\jmath}}$ & $\stackrel{\curvearrowright}{\curvearrowright}$ & $\underset{\infty}{\infty}$ & & \\
\hline \multirow[t]{3}{*}{ 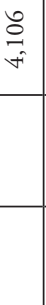 } & $\begin{array}{l}0 \\
\infty \\
\infty\end{array}$ & $\begin{array}{l}\infty \\
\infty \\
\infty \\
\infty \\
\infty\end{array}$ & 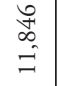 & $\overrightarrow{\bar{\lambda}}$ & है & ণి & $\overrightarrow{\tilde{\delta}}$ & $\widetilde{\widetilde{N}}$ & $\stackrel{\overrightarrow{7}}{\stackrel{2}{2}}$ & ڤू. & $\stackrel{\infty}{\stackrel{0}{=}}$ & $\underset{m}{*}$ & $\underset{\vec{\sigma}}{\vec{\sim}}$ & $\exists$ & $\stackrel{\infty}{0}$ & & \\
\hline & సิ & $\underset{\varpi_{n}}{\stackrel{0}{1}}$ & & $\underset{\rightarrow}{\mathbb{I}}$ & $\stackrel{\text { }}{\rightarrow}$ & 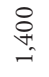 & $\underset{\sim}{\stackrel{\infty}{+}}$ & $\underset{\overbrace{}}{\stackrel{\leftrightarrow}{\sigma}}$ & & $\overrightarrow{\widehat{ત}}$ & $\begin{array}{l}\infty \\
m_{n}\end{array}$ & $\stackrel{\infty}{n}$ & $\stackrel{\hat{Q}}{\stackrel{+}{n}}$ & Fै & $\underset{\sigma}{\stackrel{\sigma}{a}}$ & & \\
\hline & ્ָخ & $\begin{array}{l}n \\
\infty \\
i \\
i\end{array}$ & & $\hat{n}_{i}^{n}$ & $\stackrel{\text { }}{\stackrel{1}{1}}$ & $\underset{i}{\mathbb{N}}$ & $\stackrel{n}{\stackrel{1}{1}}$ & $\underset{\infty}{\infty_{n}}$ & & 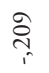 & $\cong$ & $\stackrel{\circ}{\grave{\lambda}}$ & 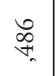 & $\underset{\nabla}{ \pm}$ & $\hat{o}$ & & \\
\hline 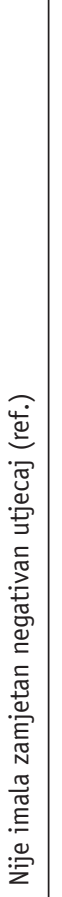 & 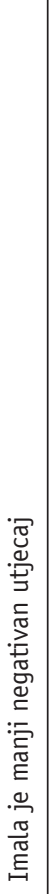 & 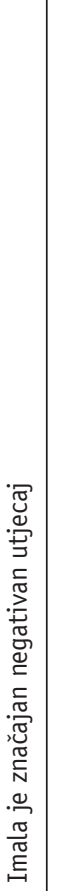 & 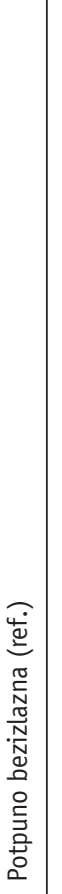 & 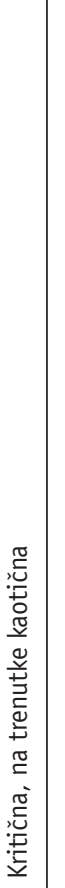 & 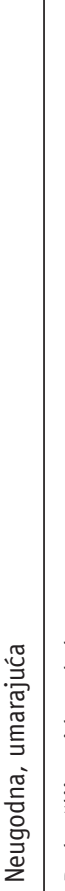 & 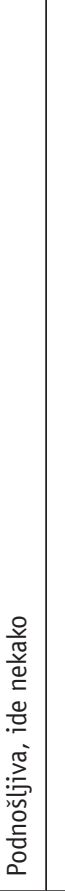 & 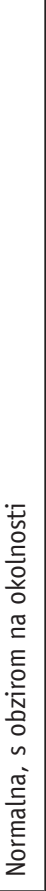 & 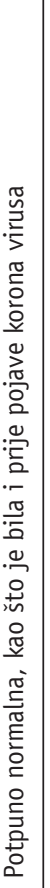 & 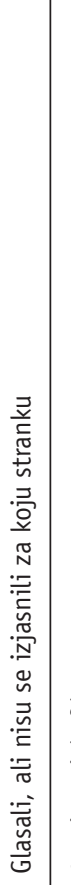 & 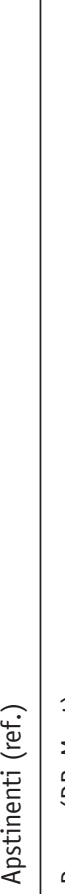 & \multicolumn{2}{|c|}{ 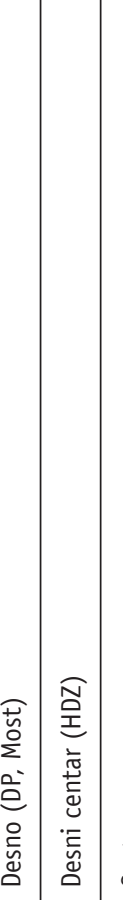 } & 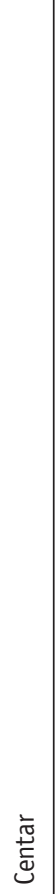 & 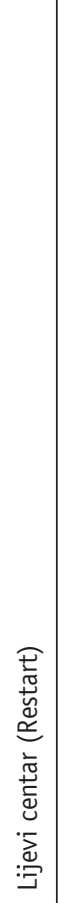 & 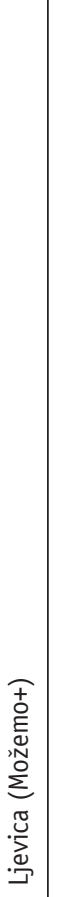 & $\begin{array}{l}: \\
\text { n్ }\end{array}$ & 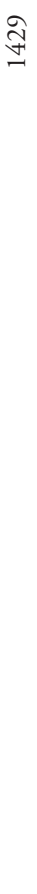 \\
\hline \multicolumn{3}{|c|}{ 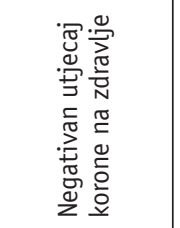 } & \multicolumn{6}{|c|}{ 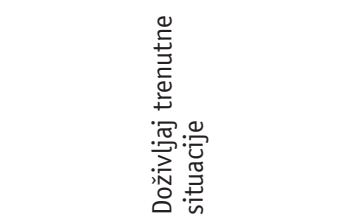 } & \multicolumn{7}{|c|}{ 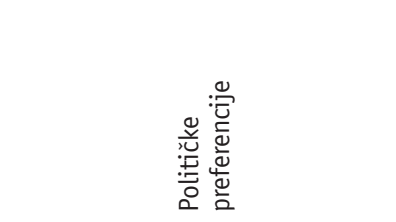 } & 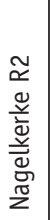 & $z$ \\
\hline
\end{tabular}


Od sociodemografskih karakteristika, dob se pokazuje kao relativno konzistentan prediktor na način da za one koji su između 40. i 49. godine života postoji 0,4 puta veća šansa da neće biti skloni antimaskerskoj reakciji u usporedbi s onima koji su između 18. i 29. godine života (referentna kategorija). Ista je razlika prisutna i kod onih koji su stariji od 65 godina u usporedbi s referentnom kategorijom. Uz taj indikator statistička značajnost prisutna je i kod obrazovanja kao prediktora antimaskerske orijentacije. U modelu se pokazuje kako je 3,1 puta veća šansa kod onih sa sekundarnom obrazovnom razinom da budu antimaskeri u usporedbi s onima koji imaju primarnu obrazovnu razinu (referentna kategorija). Ostale sociodemografske karakteristike ne pokazuju se značajnima u predikciji sklonosti antimaskerstvu.

Od prediktora egzistencijalnih uvjeta koji bi mogli biti relevantni u oblikovanju antimaskerske reakcije, značajnim se pokazuju indikator klasnih razlika (indikator ESeG), indikator radnog statusa i prihodi kućanstva. Kada se promatra klasni prediktor koji u svoju troklasnu shemu (viša klasa, srednja klasa i radnička klasa) uzima one koji su na tržištu rada, a zasebno stavlja u kategoriju sve one koji su izvan tržišta rada (nezaposlene, studente/učenike, trajno nesposobne za rad, umirovljenike, one koji se bave kućanskim poslovima i brigom za druge), evidentno je kako je šansa za antimaskersku sklonost za 0,32 puta veća kod radničke klase u usporedbi s referentnom kategorijom (viša klasa - salarijat).

Kada se pogleda efekt radnog statusa, onda je iz modela primjetno kako se sklonost antimaskerstvu povećava upravo kod učenika/studenata ( 0,23 puta veća šansa), pri čemu su referentna skupina umirovljenici.

Prihod kućanstva ${ }^{6}$ izražen kao ekvivalentni raspoloživi dohodak podijeljen u kvintile pokazuje kako postoji statistički značajna razlika na način da će kod onih ispitanika koji se nalaze u drugom, trećem i petom kvintilu biti veća sklonost antimaskerstvu nego kod onih u prvom kvintilu.

Povjerenje mjereno kao kompozitna mjera povjerenja pokazuje se statistički značajnim prediktorom. Oni ispitanici koji gaje nepovjerenje prema Nacionalnom stožeru civilne zaštite u pogledu upravljanja krizom, u znanstvenike da mogu pronaći lijek ili cjepivo za bolest, u medije u pogledu objektivnog izvještavanja o krizi uzrokovanom epidemijom koronavirusa, u Vladu RH u pogledu upravljanja krizom uzrokovanom epidemijom koronavirusa te $\mathrm{u}$ zdravstveni sustav $\mathrm{RH}$ u pogledu nošenja s krizom

\footnotetext{
6 Prihod u kućanstvu izračunat je prema OECD-ovom ekvivalentnom dohotku. Ekvivalentni raspoloživi dohodak računa se tako da se ukupan raspoloživi dohodak kućanstva podijeli s ekvivalentnom veličinom kućanstva izračunanom prema modificiranoj OECD-ovoj ljestvici, prema kojoj se nositelju kućanstva dodjeljuje koeficijent 1 , svakoj drugoj odrasloj osobi u kućanstvu od 14 godina i starijoj osobi koeficijent 0,5 , a djeci mlađoj od 14 godina koeficijent 0,3 (vidi: https://www.dzs.hr/Hrv Eng/publication/2020/14-01-01 01 2020.htm).
} 
uzrokovanom epidemijom koronavirusa pokazuju statistički značajnu sklonost antimaskerskoj reakciji.

Od kontekstualnih indikatora (negativan utjecaj pandemije COVID-19 na zdravlje i doživljaj trenutne situacije), samo se indikator negativnog utjecaja pandemije na zdravlje pokazuje kao relevantan prediktor. Oni ispitanici koji su doživjeli značajan negativan utjecaj na zdravlje imaju 0,4 puta manju šansu biti skloni antimaskerskoj reakciji.

\section{Diskusija i zaključak}

Sklonost alternativnim narativima tijekom pandemije nije neuobičajena pojava (Bogart i sur., 1999.; Bogart i Bird, 2003.; Klofstad i sur., 2019.), kao što ni sklonost teorijama zavjera nije karakteristika suvremenosti. No, dostupnost sadržaja koji se proizvodi kroz alternativne narative nikad nije kroz povijest bila toliko izražena kao što je to u današnje vrijeme. Od samog početka pandemije COVID-19 alternativni narativi pojavljivali su se ne samo u virtualnim prostorima već i kao dio oficijelnijih objašnjenja društvenih aktera relevantnih za upravljanje krizom. Čim su informacije o opasnosti koronavirusa počele prodirati u mainstream medije, razvijao se i prvi popularni alternativni narativ, popraćen brojnim memeovima, u kojima se uzrok nastanka tog virusa prikazivao kao nedovoljno skuhan šišmiš u juhi. Uz taj narativ paralelno se razvijao i zavjerenički narativ u kojem se uzrok nastanka virusa tražio u laboratoriju u Kini, što je doprinosilo razvoju teorije zavjere kako je virus nastao ljudskim djelovanjem. Taj je alternativni narativ pogotovo poticao američki predsjednik Donald Trump (Jaworsky i Qiaoan, 2020.). Već u veljači, nakon što se virus počeo širiti globalno i nakon čega su počele restrikcije, zatvaranja državnih granica i uvođenje epidemioloških mjera kao što je nošenje maski i držanje fizičke distance, postalo je jasno kako se osim širenja virusa SARS-CoV-2 čak i brže šire lažne vijesti i alternativni narativi. Kako se teorije zavjera pojavljuju u različitim društvenim situacijama i među različitim društvenim skupinama, promatranje sklonosti takvoj perspektivi kao obliku društvene patologije pokazuje se suviše redukcionističkim (Oliver i Wood, 2014.) i zapravo zahtijeva širi teorijski i analitički pristup u istraživanju. Shodno tome, antimaskersku društvenu reakciju uputno je promatrati iz perspektive teorija zavjera i tražiti koje su društvene determinante ključne u razumijevanju takve pojave tijekom specifične društvene situacije kao što je pandemija COVID-19.

Iz prikazanih rezultata u ovom istraživanju, iako je antimaskerska reakcija, kao pandemijski društveni refleks u kojem se umanjuje opasnost virusa SARS-CoV-2 ili čak i negira te u kojem se nametnute epidemiološke mjere percipiraju kao pretjerane, prisutna u hrvatskom društvu, ona je manjinska društvena pojava. Iako se može steći dojam da je široko prisutna tijekom pandemije, podaci pokazuju kako se radi o marginalnoj pojavnosti, koja se međutim ne smije u pandemijskim uvjetima zanemarivati jer može 
imati negativne posljedice po zdravlje stanovništva. Zato je i važno razumjeti koje su determinante u društvu relevantne u oblikovanju takve društvene reakcije.

Od samih početaka pandemije COVID-19 prisutna je i generacijska razlika u shvaćanju njene opasnosti te čak i generacijska tenzija u kojoj je ta bolest, kao smrtonosnija za stariji dio stanovništva, dovodila do društvenih reakcija u kojima se optuživalo starije kao one zbog kojih se uvode stroge mjere zatvaranja (lockdown), a onda tražilo pojedinačne primjere u kojima se starije osobe ne pridržavaju tih istih mjera. Stoga je i razumljivo kako se u ovoj analizi dob pokazuje kao konzistentan prediktor i potvrđuje kako je sklonost antimaskerskoj reakciji značajno manje prisutna kod starije populacije.

Uz dob kao relevantnu demografsku karakteristiku, sociološki promatrano zanimljivi su još neki demografski i politički faktori koji mogu objasniti pojavu sklonosti teorijama zavjera. Istraživanja provedena u SAD-u pokazuju kako su više razine sklonosti teorijama zavjera povezane s nižim razinama obrazovanja (Uscinski i Parent, 2014.), dok je u jednoj studiji potvrđeno kako se sklonost prema teorijama zavjera može pronaći više kod muškaraca, kod onih s nižim obrazovnim statusom ili pak kod nezaposlenih (Freeman i Bentall, 2017.). Kod obrazovanja se pretpostavlja kako ono osposobljuje ljude kognitivnim i afektivnim karakteristikama koje onda omogućuju stvaranje određene otpornosti prema teorijama zavjera (Douglas i sur., 2019.). No, što se tiče statusa obrazovanja i sklonosti prema teorijama zavjera, iako neka istraživanja upućuju na povezanost (Bogart i Bird, 2003.; Goerztzel, 1994.; Mancosu i sur., 2017.), ne pokazuje se zapravo jasna kauzalna veza. Slično je vidljivo i u ovoj analizi, koja je pokazala kako testirana razlika upućuje na to da je udio antimaskera prisutniji na sekundarnoj i tercijarnoj razini obrazovanja nego što je na primarnoj razini. Dakle, pokazuje se kako, suprotno očekivanjima koja proizlaze iz nekih istraživanja, obrazovanje u ovoj analizi ima suprotan efekt - viša razina obrazovanja, veća prisutnost antimaskerske reakcije. U regresijskom modelu obrazovanje se pokazuje kao statistički značajan prediktor antimaskerske sklonosti upravo kada se uspoređuje sekundarna obrazovana razina s primarnom obrazovnom razinom, te stoga možemo zaključiti kako veza između obrazovanja i sklonosti teorijama zavjera nije jednoznačna.

U ovoj analizi ključnima se pokazuju dva aspekta u razumijevanju antimaskerske društvene reakcije - egzistencijalni uvjeti i promjene tih uvjeta uslijed pandemije COVID-19 te povjerenje. Zadržimo se na prvom aspektu. U analizi se nekoliko elemenata egzistencijalnih uvjeta i njihovih promjena uslijed pandemije COVID-19 pokazuje važnim u kontekstu razumijevanju antimaskerske društvene reakcije. Sklonost antimaskerskoj reakciji prisutnija je kod onih ispitanika koji bilježe smanjivanje prihoda zbog pandemije, kao i u onim kućanstvima u kojima je zabilježen gubitak posla zbog pandemije. Također, vrlo su bitni sektor zaposlenja i radni status. Antimaskera ima dvostruko više među ispitanicima koji rade u, često prekarnom, privatnom sektoru 
naspram onih koji rade u javnom sektoru, koji nudi sigurnije oblike zaposlenja. Također je bitan i radni status: antimaskeri su u najvećoj mjeri prisutni upravo u kontingentu radno aktivnog dijela populacije, koji uključuje zaposlene i nezaposlene (u općoj populaciji oko 13\%, dok je 18\% kod zaposlenih i oko $20 \%$ kod nezaposlenih). Slične se razlike mogu pronaći i u nekim recentnijim istraživanjima, u kojima se upravo kontekst tržišta rada pokazuje relevantnim u razumijevanju sklonosti alternativnim narativima vezanima za pandemiju COVID-19 (Freeman i Bentall, 2017.).

Sklonost antimaskerskoj reakciji povezana je is klasnom pripadnošću. Kada se koristi klasni indikator (bez uključenih umirovljenika u analizi), postoje razlike s obzirom na antimaskersku reakciju, i to na način da su antimaskeri, kada se međusobno usporede tri klase u analizi, natprosječno zastupljeni unutar radničke klase (25\%). U regresijskom modelu upravo se to potvrđuje za radničku klasu kada ju usporedimo s višom klasom. Kako bi se bolje razumjele klasne razlike u kontekstu uvjeta rada za vrijeme pandemije, treba napomenuti kako čak $90 \%$ ispitanika koji pripadaju radničkoj klasi nisu radili od kuće nego su odlazili na svoja radna mjesta (u višoj klasi to je slučaj samo s 20\% ispitanika, a u srednjoj klasi sa 73\%). Isto tako $53 \%$ pripadnika radničke klase imalo je razdoblja u kojima uopće nisu radili, dok je to vrijedilo samo za 33\% pripadnika srednje klase, odnosno $26 \%$ pripadnika više klase. Skoro u istom omjeru razlika je između te tri klase u kontekstu korištenja mjera potpore koje su poslodavci koristili za očuvanje radnih mjesta. Drugim riječima, pripadnici radničke klase rade na radnim mjestima koja su prekarnija za vrijeme pandemije COVID-19. Gubitak posla uzrokovan pandemijskom situacijom ne pokazuje se statistički značajnim prediktorom antimaskerske sklonosti, no treba naglasiti kako je gubitak posla (ili ispitanika/ica i/ili članova/ica kućanstva) doživjelo samo 3,5\%.

Treba naglasiti i kako su skloni antimaskerskoj reakciji u hrvatskom društvu upravo oni koji su egzistencijalno i najugroženiji. Naime, ako zatvaranjem ekonomije dolazi do smanjenja prihoda ili porasta nezaposlenosti te samim time nastaje egzistencijalna prijetnja za neke u ovom društvu, onda je razumljivo kako te osobe mogu biti sklone riskirati svoje, a samim time i tuđe, zdravlje. Međutim, ono što je tu zanimljivo jest da je u našoj analizi kao zavisni konstrukt antimaskerske reakcije obuhvaćena i varijabla percepcije opasnosti virusa SARS-CoV-2, a ne samo stav o primjerenosti nametnutih epidemioloških mjera. To upućuje na aktivaciju mehanizma racionalizacije kod onih koji osjećaju egzistencijalnu ugrozu na način da u toj situaciji prilagođuju svoje uvjerenje. Takav je zaključak u skladu s istraživanjima percepcijske pristranosti (Jerit i Barabas, 2012.), kulturne kognicije (Kahan i sur., 2011.) i motivirane spoznaje (Hornsey i Fielding, 2017.), prema kojima su ljudi u svjetlu novih činjenica koje se protive prethodnim uvjerenjima skloniji odbaciti činjenice nego promijeniti svoja uvjerenja. No, treba ovdje naglasiti i to kako se sklonost antimaskerskoj društvenoj reakciji pojačava uslijed rasta egzistencijalne nesigurnosti zbog mjera zatvaranja tijekom pandemije, ali i da ovisi i o prijašnjim rasjedima u društvu, koji ukazuju na već postojeće društvene nejednakosti. 
Drugi važan aspekt razumijevanja antimaskerske reakcije pitanje je povjerenja u društvu. Naime, društveno povjerenje pokazuje se kao važan analitički pojam u istraživanjima teorija zavjere (Jovančević i Milićević, 2020.). Vjerujemo li znanstvenim i političkim autoritetima vrlo je često korelirano sa stupnjem društvenog povjerenja (Shao i Hao, 2020.). To pokazuju i ovdje prikazani podaci. Postoje razlike između antimaskera i onih koji nisu antimaskeri prema svim mjerenim razinama društvenog povjerenja. Antimaskeri iskazuju veće nepovjerenje prema svim segmentima mjerenog povjerenja. Najveće nepovjerenje iskazuju prema medijima u pogledu objektivnog izvještavanja o krizi uzrokovanoj bolešću COVID-19 te prema Vladi RH i Nacionalnom stožeru civilne zaštite u pogledu upravljanja krizom. Manju razinu nepovjerenja iskazuju prema znanstvenicima da mogu pronaći lijek ili cjepivo za virus SAR-CoV-2 te prema zdravstvenom sustavu RH u pogledu nošenja s krizom. Međutim, iz istraživanja povjerenja i teorija zavjere često izostaje ključan detalj - koji faktori generiraju nepovjerenje? Bez osvrtanja na taj problem objašnjenje sklonosti teorijama zavjera može poprimiti tautološki oblik. Vjerovanje u teorije zavjere posljedica je niske razine društvenog povjerenja, a nepovjerenje dolazi kao posljedica dezinformiranja kroz teorije zavjera. Otvaranje mehanizma kauzalnosti čini se kao ključan aspekt ovog područja istraživanja, na kojem tek treba raditi.

Recentna istraživanja u kontekstu pandemije COVID-19 pokazuju kako povjerenje u političke vođe za vrijeme pandemije može smanjiti percepciju rizika od okolišnih i zdravstvenih opasnosti, te čak moderirati efekt percepcije rizika među ljudima različitih političkih ideologija (Shao i Hao, 2020.), a već spomenuta istraživanja pokazuju kako se sklonost teorijama zavjera može pronaći na radikalnijim dijelovima političkog spektra (lijevog i desnog) (van Prooijen i sur., 2015; Krouwel i sur., 2018.). Iz analize u ovom radu pokazuje se kako se sklonost antimaskerskoj reakciji može pronaći primarno na desnom radikalnom polu (politička preferencija prema Domovinskom pokretu i Mostu), što potvrđuju i neka istraživanja teorija zavjera u drugim zemljama (Bruder i sur., 2013.; Grzesiak-Feldman i Irzycka, 2009.). Nešto veća naklonost glasača centra antimaskerskoj reakciji, dakle glasača stranaka u hrvatskom političkom prostoru koje su nove i bez jasno istaknutog ideološkog predznaka ljevice ili desnice (Pametno, Stranka s imenom i prezimenom, Fokus) i koje mogu biti percipirane kao nezavisne, odnosno kao treće političke opcije u dominantnom dvostranačju, također se može pronaći i u nekim provedenim istraživanjima u drugim zemljama (Uscinski i sur., 2016.). No, treba naglasiti kako se u analizi pokazalo da je izrazita prisutnost onih koji nisu antimaskeri zabilježena među glasačima HDZ-a. Jedno objašnjenje za to može biti činjenica da je HDZ trenutno vladajuća stranka koja provodi mjere borbe protiv pandemije, zbog čega glasači te stranke osjećaju manje nepovjerenje prema nametnutim mjerama, za razliku od drugih desnih i radikalno desnih glasača. Prema tome, čini se kako je pitanje političkih preferencija i antimaskerske reakcije povezano $s$ problemom povjerenja. Simpatizeri onih stranaka koje i inače mobiliziraju glasače na temelju teorija zavjere i alternativnih narativa mobiliziraju i antimaskere. Anti- 
maskerska društvena reakcija nije bila samo spontani iskaz nezadovoljstva građana već je bilo evidentno kako postoji i određeno političko uokvirivanje koja dolazi s desnog političkog spektra iz stranaka kao što su Domovinski pokret i Most. Upravo na organiziranim prosvjedima Festivala slobode bili su viđeni istaknuti članovi tih političkih opcija. Povezanost političkih aktera i političkog diskursa s teorijama zavjera u političkom prostoru hrvatskog društva nije novost. Istraživanja pokazuju kako je ta povezanost bila prisutna i prije te, kako tvrdi Blanuša, teorije zavjera možemo promatrati kao „simptome i indikatore širih društvenih problema i turbulencija, izraženih u specifično emocionalnoj i kondenziranoj formi [...] koju pronalazimo diljem Europe, a koja u sebi sadrži eksplozivni potencijal“ (Blanuša, 2020.). No, kako se u binarnom logističkom regresijskom modelu političke preferencije ne pokazuju statistički značajnom determinantom, čini se kako je političko koketiranje s antimaskerskim narativom više u svojim počecima nego što ga možemo doživjeti kao ekspoziciju političke naracije uokvirene teorijama zavjera. U tom kontekstu potrebna je daljnja eksploracija povezanosti političke identifikacije i društvenih reakcija tijekom pandemije.

Historijsko-antropološka istraživanju pokazuju da su maske i maskiranje prisutni u većini, ako ne i svim ljudskim društvima i iako je manipulacija ljudskim licem kroz maskiranje bila vrlo raširena aktivnost kroz veći dio čovjekove povijesti, u tom smislu sociologija ni kroz povijest a ni danas nije zainteresirana za maske i maskiranje jer se nije pronalazila relevantnost takvih društvenih praksi (Inglis, 2020.). No, borba s pandemijom COVID-19 uključuje nošenje maski upravo kao jednu od ključnih epidemioloških mjera. Od samih početaka ove pandemije upravo se koncept nošenja maski čini kao poprište različitih društvenih silnica i testiranja sociopolitičkih i socioekonomskih ideja. Nošenje maski time prestaje biti puka epidemiološka mjera u borbi s pandemijom i postaje relevantna sociološka tema povezana sa zdravljem i medicinom, smrću i umiranjem, društvenim nejednakostima, političkim borbama i ekonomskim strategijama.

Istraživanje antimaskerstva u ovom radu temelji se na prikupljenim podacima iz anketnog istraživanja koje je provedeno na punoljetnim građanima RH kojim se ispitivalo stavove o koroni te ponašanje u odnosu na mjere. Korišteni anketni upitnik pritom je, dakako, sastavljen u odnosu na kontekst hrvatskog društva. S obzirom na to da su se mjere za suzbijanje širenja bolesti COVID-19 značajno razlikovale po zemljama - vrlo često zavisno od specifičnih institucionalnih i političkih kultura, strukovnih epidemioloških tradicija i sl. - jasno je da se nalazi na temelju prikupljenih podataka u hrvatskom društvu ne mogu koristiti za objašnjavanje fenomena protivljenja epidemiološkim mjerama u drugim zemljama. Međutim, imajući to u vidu, smatramo da protivljenje i prosvjedi protiv epidemioloških mjera u različitim zemljama do određene razine dijele zajedničke karakteristike (mobilizacijske poruke, komunikacijsku strategiju, regrutacijske obrasce), što upućuje na to kako analiza hrvatskih podataka ima i širu relevantnost od objašnjenja isključivo slučaja hrvatskog društva. 
Ograničenja u ovoj studiji odnose se na određene izazove s uzrokom (nije optimalan probabilistički uzorak zbog neažuriranog okvira za izbor uzorka), na relativno visoku stopu odbijanja, koja možda upućuje na ograničenost u zahvaćanju onih koji bi mogli imati i radikalnije stavove o pandemiji COVID-19 (dodatnih antimaskera), te što se radi o uvidu u društvo prije pojačanog jesensko/zimskog vala oboljenja i uvođenja restriktivnijih protektivnih mjera. $U$ tom smislu potrebno je nastaviti istraživati tu pojavu za vrijeme pandemije, što bi podrazumijevalo i korištenje kvalitativnih metodoloških nacrta kako bi se stekao boji uvid u razlike antimaskerske perspektive i razumijevanje društvenih uvjeta koji pogoduju razvijanju sklonosti teorijama zavjera.

\section{Literatura}

1. Abalakina-Paap, M.; Stephan, W. G.; Craig, T.; Gregory, W. L. (1999). Beliefs in conspiracies. Polit. Psychol., 20: 637-647. https://doi.org/10.1111/0162895X.00160.

2. Ančić, B.; Baketa, N. and Kovačić, M. (2019a). Exploration of Class and Political Behavior in Croatia Exploration of Class and Political Behavior in Croatia. Int. J. Sociol., 49: 1-17. https://doi.org/10.1080/00207659.2019.1634826.

3. Ančić, B.; Domazet, M. and Župarić-Iljić, D. (2019b). "For my health and for my friends": Exploring motivation, sharing, environmentalism , resilience and class structure of food self-provisioning. Geoforum, 106: 68-77. https://doi. org/10.1016/j.geoforum.2019.07.018.

4. Bagić, D. i Šuljok, A. (2021). „Stavi masku i odmakni se“ - istraživanje determinanti protektivnog ponašanja od bolesti COVID-19 u Hrvatskoj. Sociologija i prostor, 219 (Posebno izdanje): 119-147.

5. Blanuša, N. (2020). Conspiracy Theories in and About the Balkans. Routledge Handb. Conspir. Theor. 596-609. https://doi.org/10.4324/978042945273456.

6. Bogart, L. M.; Bird, S. T. (2003). Exploring the relationship of conspiracy beliefs about HIV/AIDS to sexual behaviors and attitudes among African-American adults. J. Natl. Med. Assoc., 95: 1057-1065.

7. Bogart, L. M.; Wagner, G.; Galvan, F. H.; Banks, D. (1999). Conspiracy Beliefs about HIV Are Related to Antiretroviral Treatment Nonadherence among African American Men with HIV. J. of Acquired Immune Defic., Syndr. 53: 648-655. https://doi.org/10.1097/QAI.0b013e3181c57dbc.Conspiracy.

8. Bruder, M.; Haffke, P.; Neave, N.; Nouripanah, N.; Imhoff, R. (2013). Measuring Individual Differences in Generic Beliefs in Conspiracy Theories Across Cultures: Conspiracy Mentality Questionnaire. Front. Psychol., 4. https://doi. org/10.3389/fpsyg.2013.00225.

9. Cichocka, A.; Marchlewska, M.; Golec de Zavala, A.; Olechowski, M. (2016). "They will not control us": Ingroup positivity and belief in intergroup conspiracies. Br. J. Psychol., 107: 556-576. https://doi.org/10.1111/bjop.12158. 
10. Crocker, J.; Luhtanen, R.; Broadnax, S.; Blaine, B. E. (1999). Belief in U.S. Government conspiracies against blacks among black and white college students: Powerlessness or system blame? Personal. Soc. Psychol. Bull., 25: 941-953. https://doi.org/10.1177/01461672992511003.

11. Douglas, K. M.; Sutton, R. M. and Cichocka, A. (2017). The psychology of conspiracy theories. Curr. Dir. Psychol. Sci., 26: 538-542. https://doi. org/10.1177/0963721417718261.

12. Douglas, K. M.; Uscinski, J. E.; Sutton, R. M.; Cichocka, A.; Nefes, T.; Ang, C. S.; Deravi, F. (2019). Understanding Conspiracy Theories. Polit. Psychol., 40: 3-35. https://doi.org/10.1111/pops.12568.

13. Edelson, J.; Alduncin, A.; Krewson, C.; Sieja, J. A.; Uscinski, J. E. (2017). The effect of conspiratorial thinking and motivated reasoning on belief in election fraud. Polit. Res. Q., 70: 933-946. https://doi.org/10.1177/1065912917721061.

14. Freeman, D. and Bentall, R. P. (2017). The concomitants of conspiracy concerns. Soc. Psychiatry Psychiatr. Epidemiol., 52: 595-604. https://doi.org/10.1007/covid-19s00127-017-1354-4.

15. Geissler, E. and Sprinkle, R. H. (2013). Disinformation squared: Was the HIVfrom-Fort-Detrick myth a Stasi success?. Polit. Life Sci., 32: 2-99. https://doi. org/10.2990/32 22 .

16. Goerztzel, T. (1994). Belief in Conspiracy Theories. Polit. Psychol., 15: 731-742.

17. Graeupner, D. and Coman, A. (2017). The dark side of meaning-making: How social exclusion leads to superstitious thinking. J. Exp. Soc. Psychol., 69: 218222. https://doi.org/10.1016/j.jesp.2016.10.003.

18. Grzesiak-Feldman, M. (2013). The Effect of High-Anxiety Situations on Conspiracy Thinking. Curr. Psychol., 32: 100-118. https://doi.org/10.1007/s12144013-9165-6.

19. Grzesiak-Feldman, M. and Irzycka, M. (2009). Right-wing authoritarianism and conspiracy thinking in a polish sample. Psychol. Rep., 105: 389-393. https:// doi.org/10.2466/PR0.105.2.389-393.

20. Holý, D. and Strašilová, G. (2015). Risk of Unemployment and Earnings Levels by Socio-Economic Group - Introduction of ESeG Classification. STATISTIKA, 95: 33-43.

21. Hornsey, M. J. and Fielding, K. S. (2017). Attitude roots and Jiu Jitsu persuasion: Understanding and overcoming the motivated rejection of science. Am. Psychol., 72: 459-473. https://doi.org/10.1037/a0040437.

22. Imhoff, R. and Bruder, M. (2014). Speaking (Un-)truth to power: Conspiracy mentality as a generalised political attitude. Eur. J. Pers., 28: 25-43. https://doi. org/10.1002/per.1930.

23. Imhoff, R. and Lamberty, P. (2020). A Bioweapon or a Hoax? The Link Between Distinct Conspiracy Beliefs About the Coronavirus Disease (COVID-19) Outbreak and Pandemic Behavior. Soc. Psychol. Personal. Sci., 11: 1110-1118. https://doi.org/10.1177/1948550620934692. 
24. Inglis, D. (2020). Masking - Corona-Masquerade, or: Unmasking the New Sociology of Masks. PANDEMIC (IM)POSSIBILITIES 1.

25. Jaworsky, B. N. and Qiaoan, R. (2020). The Politics of Blaming: the Narrative Battle between China and the US over COVID-19. J. Chinese Polit. Sci. https:// doi.org/10.1007/s11366-020-09690-8.

26. Jerit, J. and Barabas, J. (2012). Partisan perceptual bias and the information environment. J. Polit., 74: 672-684. https://doi.org/10.1017/S0022381612000187.

27. Jolley, D. and Douglas, K. M. (2014). The social consequences of conspiracism: Exposure to conspiracy theories decreases intentions to engage in politics and to reduce one's carbon footprint. Br. J. Psychol., 105: 35-56.

28. Jost, J. T.; Glaser, J.; Kruglanski, A. W.; Sulloway, F. J. (2003). Political Conservatism as Motivated Social Cognition. Psychol. Bull., 129: 339-375. https:// doi.org/10.1037/0033-2909.129.3.339.

29. Jovančević, A. and Milićević, N. (2020). Optimism-pessimism, conspiracy theories and general trust as factors contributing to COVID-19 related behavior - A cross-cultural study. Pers. Individ. Dif., 167: 110216. https://doi.org/10.1016/j. paid.2020.110216.

30. Kahan, D. M.; Jenkins-Smith, H. and Braman, D. (2011). Cultural cognition of scientific consensus. J. Risk Res., 14: 147-174. https://doi.org/10.1080/1366 9877.2010.511246.

31. Keeley, B. L. (1999). Of conspiracy theories. J. Philos., 96: 109-126. https://doi. org/10.4324/9781315259574-4.

32. Klofstad, C. A.; Uscinski, J. E.; Connolly, J. M.; West, J. P. (2019). What drives people to believe in Zika conspiracy theories?. Palgrave Commun., 5: 1-8. https://doi.org/10.1057/s41599-019-0243-8.

33. Kofta, M. and Sedek, G. (2005). Conspiracy Stereotypes of Jews During Systemic Transformation in Poland. Int. J. Sociol., 35: 40-64. https://doi.org/10.10 80/00207659.2005.11043142.

34. Krouwel, A.; Kutiyski, Y.; van Prooijena, J. W.; Martinsson, J.; Markstedt, E.; (2018). Does extreme political ideology predict conspiracy beliefs, economic evaluations and political trust? Evidence from Sweden. J. Soc. Polit. Psychol., 5: 435-462. https://doi.org/10.5964/jspp.v5i2.745.

35. Leman, P. J. and Cinnirella, M. (2013). Beliefs in conspiracy theories and the need for cognitive closure. Front. Psychol., 4: 1-10. https://doi.org/10.3389/fpsyg.2013.00378.

36. Mancosu, M.; Vassallo, S. and Vezzoni, C. (2017). Believing in Conspiracy Theories: Evidence from an Exploratory Analysis of Italian Survey Data. South Eur. Soc. Polit., 22: 327-344. https://doi.org/10.1080/13608746.2017.13598 $\underline{94 .}$

37. Moore, A. (2018). On the democratic problem of conspiracy theory politics, in: Uscinski, J. E. (Ed.). Conspiracy Theories and People Who Believe Them. Oxford University Press, New York, pp. 111-121. 
38. Oliver, J. E. and Wood, T. J. (2014). Conspiracy theories and the paranoid style(s) of mass opinion. Am. J. Pol. Sci., 58: 952-966. https://doi.org/10.1111/ ajps.12084.

39. Pigden, C. (1995). Popper revisited, or what is wrong with conspiracy theories?. Philos. Soc. Sci., 25: 3-34. https://doi.org/10.4324/9781315259574-3.

40. Shao, W. and Hao, F. (2020). Confidence in political leaders can slant risk perceptions of COVID-19 in a highly polarized environment. Soc. Sci. Med., 261: 113235. https://doi.org/10.1016/j.socscimed.2020.113235.

41. Sunstein, C.R. and Vermeule, A. (2008). Conspiracy theories. Univ. Chicago Law Sch. Public Law Leg. Theory Res. Pap. Ser. 387. https://doi.org/10.5840/inquiryctnews2004/2005241/29.

42. Swami, V. and Furnham, A. (2014). Political paranoia and conspiracy theories. Power, Polit. Paranoia Why People are Suspicious their Leaders 9781107035, 218-236. https://doi.org/10.1017/CBO9781139565417.016.

43. Tijdens, K. (2016). ESEG-2014 coding scheme + explanatory note.

44. Uscinski, J. E. and Parent, J. M. (2014). American conspiracy theories. New York: Oxford University Press.

45. Uscinski, J. E.; Klofstad, C. and Atkinson, M. D. (2016). What Drives Conspiratorial Beliefs? The Role of Informational Cues and Predispositions. Polit. Res. Q., 69: 57-71. https://doi.org/10.1177/1065912915621621.

46. van Prooijen, J. W. and Acker, M. (2015). The Influence of Control on Belief in Conspiracy Theories: Conceptual and Applied Extensions. Appl. Cogn. Psychol., 29: 753-761. https://doi.org/10.1002/acp.3161.

47. van Prooijen, J. W.; Krouwel, A. P .M. and Pollet, T. V. (2015). Political Extremism Predicts Belief in Conspiracy Theories. Soc. Psychol. Personal. Sci., 6: 570-578. https://doi.org/10.1177/1948550614567356. 


\title{
Who are the Anti-Maskers in Croatia? A Contribution to the Research on the Anti-Masker Reaction during the COVID-19 Disease Pandemic in Croatia
}

\author{
Branko Ančić \\ Institute for Social Research in Zagrebu, Croatia \\ e-mail: branko@idi.hr \\ Dražen Cepić \\ University of Zadar, Department of Sociology, Croatia \\ e-mail:dcepic@unizd.hr
}

\begin{abstract}
Since the very beginning of the COVID-19 disease pandemic there have been alternative narratives, not only in virtual spaces, but also as part of official explanations given by social actors relevant for managing the pandemic crisis. As a reaction to the disease spread, authorities everywhere introduced quarantine measures, obligatory adherence to epidemiological measures, and economic lockdown, which led to protests against the measures in a number of cities worldwide, such as Berlin, London, Brussels, Dublin, Madrid, Paris, Rotter $\neg$ dam, even Zagreb (so-called anti-mask protests) during the summer and throughout the autumn and winter of 2020. In this paper, the notion of anti-mask attitude is viewed as a social phenomenon implying not only a mere fact of not wearing a mask as an act of violating epidemiological measures, but also the reaction of people during the pandemic. This reaction is comprised of the perception diminishing the danger of the SARS-CoV-2 virus or even denying its existence, along with the assessment that the imposed epidemiological measures are oppressive (too stringent). The theoretical framework of the paper is based on literature on conspiracy theories as an overarching concept that helps understand the anti-mask movements. In the analysis, the data gathered by a questionnaire survey (CATI technique) during August, September and October 2020 on a nationally representative sample $(\mathrm{N}=1512)$ were used. In the paper, some determinants of inclination towards conspiracy theories were analysed as possible explanatory determinants of the anti-masker social reaction. The analysis pointed to two aspects appearing as key for understanding the anti-masker social reaction - existential conditions and the changes of these conditions due to the pandemic, and trust in relevant social actors' / institutions' management of the COVID-19 disease induced crises.
\end{abstract}

Key words: COVID-19 disease pandemic, anti-mask attitude, conspiracy theories, adherence to epidemiological measures. 